\title{
Realized Bank Risk during the Great Recession
}

Altunbas, Yener, Simone Manganelli, and David Marques-Ibanez

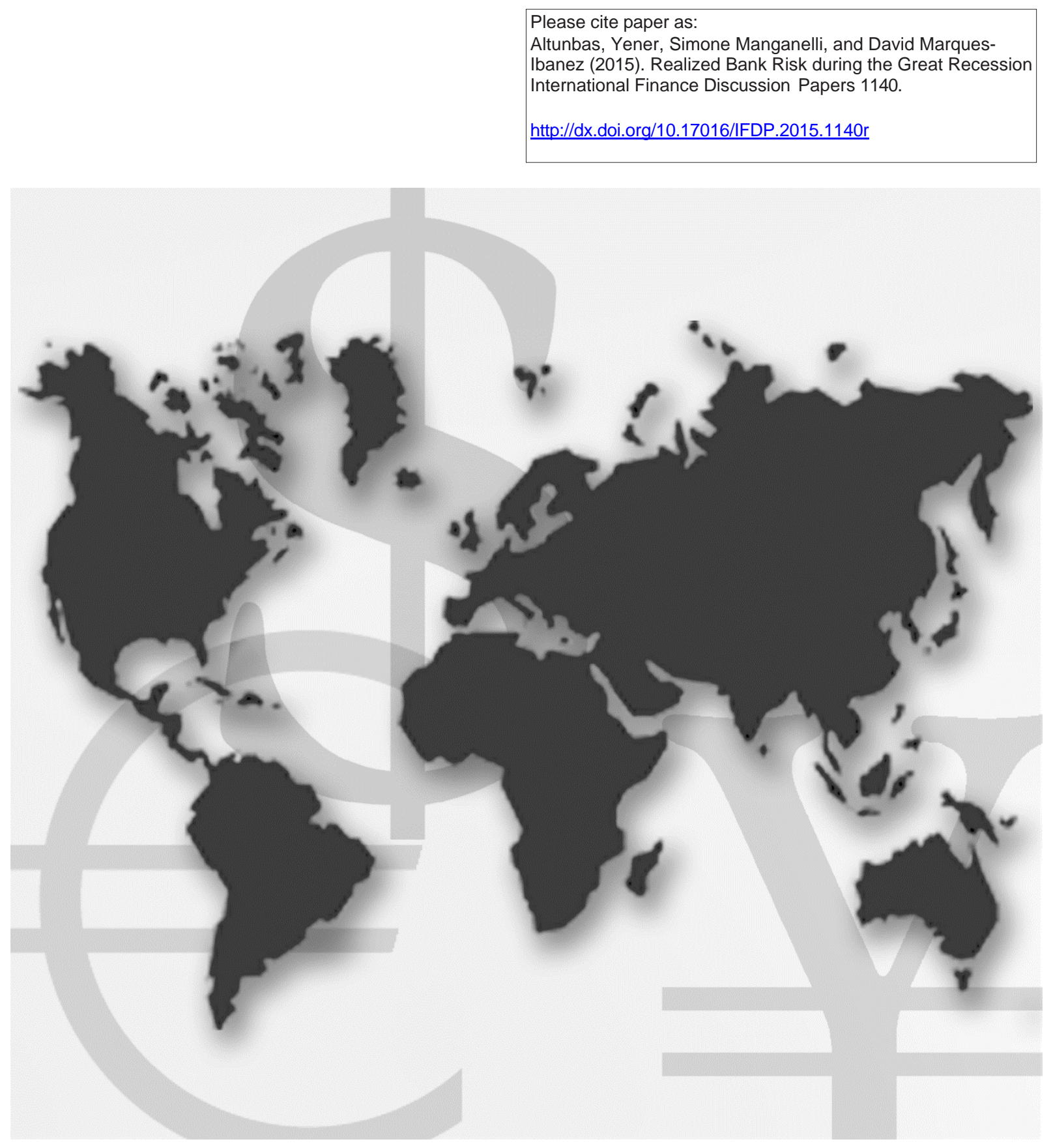

\section{International Finance Discussion Papers}

Board of Governors of the Federal Reserve System

Number 1140r

October 2015 
Board of Governors of the Federal Reserve System

International Finance Discussion Papers

Number 1140r

October 2015

\title{
Realized Bank Risk during the Great Recession
}

\author{
Yener Altunbas \\ Simone Manganelli \\ David Marques-Ibanez
}

NOTE: International Finance Discussion Papers are preliminary materials circulated to stimulate discussion and critical comment. References to International Finance Discussion Papers (other than an acknowledgment that the writer has had access to unpublished material) should be cleared with the author or authors. Recent IFDPs are available on the Web at www.federalreserve.gov/pubs/ifdp/. This paper can be downloaded without charge from the Social Science Research Network electronic library at www.ssrn.com. 


\title{
Realized Bank Risk during the Great Recession
}

\author{
Yener Altunbas
}

Simone Manganelli

David Marques-Ibanez*

\begin{abstract}
In the years preceding the 2007-2009 financial crisis, forward-looking indicators of bank risk suggested unusually low expectations of bank default. We assess whether the ex-ante (i.e. prior to the crisis) crosssectional variability in bank characteristics is related to the ex-post (i.e. during the crisis) materialization of bank risk. Our tailor-made dataset crucially accounts for the different dimensions of realized bank risk including access to central bank liquidity during the crisis. We consistently find that less reliance on deposit funding, more aggressive credit growth, larger size and leverage were associated with larger levels of realized risk. The impact of these characteristics is particularly relevant for capturing the systemic dimensions of bank risk and tends to become stronger for the tail of the riskier banks. The majority of these characteristics also predicted bank risk as materialized before the financial crisis.
\end{abstract}

Keywords: Bank risk; business models; great recession

JEL classification: G21; G15; E58; G32

\footnotetext{
* David Marques-Ibanez (David.Marques-Ibanez@frb.gov): Division of International Finance at the Board of Governors of the Federal Reserve System. Yener Altunbas (Y.Altunbas@bangor.ac.uk): Bangor Business School, Bangor University. Simone Manganelli (Simone.Manganelli@ecb.int): Directorate General Research, European Central Bank. The views expressed in this paper are solely the responsibility of the authors and should not be interpreted as reflecting the views of the Board of Governors of the Federal Reserve System, or the European central Bank, or of any other person associated with the Federal Reserve System or the European Central Bank. We thank, in particular, Charles Calomiris, Tobias Adrian, Thorsten Beck, Geert Bekaert, Allen Berger, Mark Carey, Stijn Claessens, Giancarlo Corsetti, Andrew Ellul, Charles Engel, Leonardo Gambacorta, Reint Gropp, Philipp Hartmann, Harald Hau, Florian Heider, Harry Huizinga, Sam Langfield, Jyoti Patel, Jose Peydro, Alexander Popov, Alberto Franco Pozzolo, John Rogers, Klaus Schaeck and Philipp Schnabl for their very useful comments. We are also grateful to Francesca Fabbri, Luiz Paulo Fichtner and Silviu Oprica for their help in obtaining data. We thank the participants at the seminars held at Bank of England, Board of Governors of the Federal Reserve System, Tilburg University, University of Geneva, Luxembourg School of Finance, University of Bergen, Bank for International Settlements, European Central Bank, at the conference on Global Systemic Risk (organized by the Federal Reserve Bank of New York and New York University) and on the 48th annual conference on Bank Structure and Competition (organized by the Federal Reserve Bank of Chicago) for their valuable insights.
} 
The 2007-2009 financial crisis resulted in the largest realization of bank risk since the Great Depression, producing record levels of unemployment and giving way to what is now referred to as the "Great Recession”. Banks' market capitalisation in Europe and the United States decreased by 82\% between May 2007 and March 2009. The crisis revealed also huge variability across individual banks, as evidenced by the increased dispersion of cross-sectional stock market returns after the crisis, suggesting a strong degree of heterogeneity in ex-ante risk-taking. Surprisingly, most indicators of bank risk in the years preceding the crisis showed, first, a fairly benign picture, as shown for instance by the forward-looking measures regularly used by financial institutions, investors, central banks, and regulators to monitor the health of the financial system (IMF, 2009). Second, these signals of bank risk were also highly clustered across institutions, making it difficult to disentangle ex-ante between riskier and safer institutions (see Figure I).

These developments on markets' perceptions of bank risk were especially important, as much of the supervisory action had progressively moved away from regulating banks' activities and business models towards an increased reliance on market discipline (often exercised by market based indicators) as the preferred source of constraint on risk-taking behaviour. Partly as a result of this stronger reliance on market-based indicators to assess bank risk, supervisors, rating agencies and financial practitioners have repeatedly pointed to the benign outlook provided by market-based indicators prior to the crisis to emphasise the unexpected dimension of the recent crisis. ${ }^{1}$

Despite this move away from regulating banks' business models, most of the previous literature tended to find a strong link between certain bank characteristics and risk. At the same time, this literature also showed some limitations regarding the consistency of the findings or contradictions on the impact of certain variables on bank risk that limited its applicability for practical purposes.

\footnotetext{
${ }^{1}$ See for instance Gorton (2012).
} 
The objective of our paper is to understand to what extent the ex-ante variability in bank characteristics often associated with higher likelihood of bank default would consistently help in the early identification of risks. A critical challenge is how to incorporate the different dimensions of realised bank risk so the consistency of the results can be assessed. Using a database laboriously compiled for the purposes of this study we incorporate six different measures of bank risk and analyse how different measures of bank distress are related to balance sheet characteristics in the pre-crisis period. Building on the pre-crisis literature (see for instance the extensive survey provided in Berger, Molyneux and Wilson, 2015), we group individual bank information into four broad categories - capital, asset, funding, and income structures - which concisely summarize the underlying, bank business models. We have three sets of findings.

First, we show that bank size, the rate of credit expansion, lower dependence on customer deposits, and a weaker capital base for undercapitalised banks in the run-up to the crisis consistently accounted for higher levels of ex-post distress. The impact of these bank characteristics is particularly stronger for the systemic dimension of bank risk. Importantly, while these characteristics consistently predict all broad measures of bank distress, their predictive impact on idiosyncratic measures of bank risk is negligible. These results are robust to the inclusion of a series of macroeconomic and institutional controls, as well as the use of instruments to account for potential endogeneity between the dependent variable and the regressors.

Second, we also re-run our baseline estimations using all available measures of bank risk prior to the crisis. The idea is to ascertain whether the muted expectations of bank risk by market participants and banking supervisors prior to the crisis could be linked to a lack of predictability of bank characteristics on risk before a crisis takes place. We find that bank characteristics clearly predicted risk also prior to the 
crisis. Also in this setting, we find that their impact is considerably stronger for the systemic dimension of bank risk. We illustrate this point graphically by showing that banks with high relative systematic risk before the crisis were also those institutions with the higher systematic risk during the crisis, thereby buttressing the argument of ex-ante predictability.

Third, we show that the effect of balance sheet variables on bank risk is non-linear. This impact was identified by estimating a quantile regression to reveal whether the risk determinants of the riskiest banks (those belonging to the upper part of the cross-sectional distribution of distress during the crisis) are similar to those of the less risky banks (those belonging to the lower part of the same distribution). In the event of a crisis, we find that the degree of sheltering from bank risk provided by capital and deposit funding becomes stronger as realized risk increases. The direct impact of loan growth on risk is more important (up to three times larger) for the quantiles of banks with the higher levels of realized risk while dependence on short-term market funding seems to be a particularly aggravating factor for the group of the riskier banks. This suggests that banks with these balance sheet characteristics deserve closer monitoring, as they are more likely to display higher levels of distress during a crisis.

Our findings have a bearing on the current prudential regulatory debate. They suggest that aggressive loan growth and excessive reliance on short-term market funding lead to the accumulation of risk, thereby supporting the introduction of capital and liquidity charges linked to these variables. They are also in line with the Basel III initiatives aimed at raising the capital levels of institutions, in particular of undercapitalized ones (see BIS, 2010). The remainder of this paper is organized as follows. Section I reviews the literature on bank characteristics and risk. Section II describes the model, data sources, and how the dataset was constructed. Section III presents the main empirical findings and section IV the robustness tests. Section V concludes. 


\section{Band risk and business models: a literature review}

We structure our review of the literature by grouping bank characteristics into four main broad categories, used later in our empirical investigation.

Capital structure - The literature offers contradictory results as to the effects of capital on bank risk (Freixas and Rochet, 2008). In principle, the higher the capital, the stronger the buffer to withstand losses. Higher levels of capital - by increasing the skin in the game of shareholders - may also reduce risk-shifting incentives towards excessively risky projects at the expense of debt holders. While this is true in general for any firm, it is especially so in the banking industry, where the presence of deposit insurance creates an additional incentive for shareholders to take advantage of this guarantee by taking on excessive risks (Bhattacharya and Thakor, 1993).

There are related reasons that could bring about a positive relationship between capital and risk. For instance, agency problems between shareholders and managers can lead to excessive risk-taking via managerial rent-seeking. According to the corporate finance literature, higher leverage (and therefore lower levels of capital) reduces agency conflicts between managers and shareholders, since informed debt holders intensify the pressure on bank managers to become more disciplined (Jensen and Meckling, 1976; Calomiris and Kahn, 1991; Diamond and Rajan, 2001). It is also possible to envisage a non-linear relationship, whereby both very low and very high levels of capital induce banks to take on more risk (Calem and Rob, 1999). Empirically, higher levels of capital may simply be the result of regulators forcing riskier banks to hold higher buffers. There is, in fact, some evidence finding a positive relationship between higher levels of bank capital and risk (see for instance Delis and Staikouras, 2011). ${ }^{2}$ At the same

\footnotetext{
${ }^{2}$ In fact many of the banks failing during the crisis had capital levels above the average of their peers (Haldane and Madouros, 2012).
} 
time, most of the empirical literature tends to support the view that holding more capital supports bank soundness particularly during crises (Demirgüç-Kunt and Huizinga, 2010; Berger and Bouwman, 2013).

Asset structure - The widespread use of private securitization techniques represented a major structural development in the decades prior to the 2007-2009 crisis. It allowed banks to actively manage the asset structure their balance sheet, by off-loading part of the loans in their books to financial market investors. In particular, it permitted banks to swiftly turn traditionally illiquid claims (overwhelmingly in the form of bank loans) into marketable securities. This, in turn, lowered banks' regulatory pressures on capital requirements (Shin, 2009; Marques-Ibanez and Scheicher, 2010). In principle, from the perspective of individual banks, securitization helped banks to manage and diversify their credit risk portfolio more effectively, both geographically and by sector. Indeed, most of the empirical evidence from the pre-crisis period suggests that banks that were more active in the securitization market were often found to have lower solvency risk, higher profitability levels, and were also better capitalized (Cebenoyan and Strahan, 2004; Wu et al., 2011). At the same time, banks might also respond to the static reduction in risks due to securitization by taking on new ones, for instance by loosening their lending standards, increasing their leverage, or becoming systemically riskier (Mian and Sufi, 2009; Nijskens and Wagner, 2011; Keys et al., 2010).

Funding structure - Banks’ traditional source of funding is represented by customers' deposits. It is well known that high switching costs and the presence of government insurance makes retail deposits a stable source of funding also during periods of crisis (Kim et al., 2003; Shleifer and Vishny, 2010). Deposits, however, are often less flexible in adapting to changes in financing needs (for instance, to fund new investment opportunities) compared to wholesale markets' sources of financing, where funds are usually raised on a rollover basis through instruments such as mortgage bonds, repurchase agreements and commercial paper. According to earlier literature, financial market investors - being relatively more 
sophisticated than retail depositors - could provide useful market discipline (Calomiris and Kahn, 1991). At the same time, the recent financial crisis pointed also to a "dark side" of market funding underlying some limitations on the monitoring ability of wholesale investors for systemic risks during certain periods (Huang and Ratnovski, 2011; Gorton and Metrick, 2012).

Income structure - Historically, most systemic banking crises have been preceded by periods of excessive lending (Reinhart and Rogoff, 2009). This is confirmed by microeconomic evidence from large international banks, which shows that loan growth represents an important driver of risk (Laeven and Majnoni, 2003; Foos et al., 2010). The global trend towards more diversification in bank income sources has led to an expansion of non-interest income revenues, such as those derived from trading, investment banking, brokerage fees and commissions. Such diversification can, in principle, foster stability in banks’ overall income (Stiroh, 2010). At the same time, it is not clear whether the stronger reliance on noninterest income reduces overall banking risk. Since this type of income tends to be a particularly volatile source of revenue, it may suffer more in periods of financial stress. As a result, it is also possible that the financial stability benefits that may be obtained from diversification accrue only in cases of minor idiosyncratic risk, but not in the context of a wider systemic shock (De Jonghe, 2010; Brunnermeier et al. 2012).

Finally, a handful of studies have focused on the determinants of stock market performance for large banks during the recent crisis (Beltratti and Stulz, 2012; Bekaert et al., 2014; Demirgüç-Kunt et al., 2010). Beltratti and Stulz (2012) find that banks with higher capital (in countries with stronger capital supervision) and lower loan to total assets ratio performed better in the initial stages of the crisis, while banks with more shareholder-friendly boards performed worse. Size can also be an important determinant of banks’ risk (Huang et al., 2012; Tarashev et al., 2009; Laeven et al., 2014). Compared to smaller banks, 
larger institutions could have different incentives due to the "too-big-to-fail" problem or diversification possibilities (Demirgüç-Kunt and Huizinga, 2010).

\section{Construction of bank risk variables}

Our baseline specification draws on the previous discussion, grouping the variables by balance sheet structures:

$$
\begin{aligned}
r_{i, c}=\beta_{0}+\beta_{1} \operatorname{Size}_{i, b} & +\underbrace{\beta_{2} \text { Capital }_{i, b}+\beta_{3} \text { Undercapitalized }_{i, b}}_{\text {Capital structure }}+ \\
& +\underbrace{\beta_{4} \text { Loan to total assets }_{i, b}+\beta_{5} \text { Securitization }_{i, b}}_{\text {Asset structure }}+ \\
& +\underbrace{\beta_{6} \text { Short - term market funding }_{i, b}+\beta_{7} \text { Deposit funding }_{i, b}}_{\text {Funding structure }}+ \\
& +\underbrace{\beta_{8} \text { Excessive loan growth }_{i}}_{\text {Income structure }_{i, b}+\beta_{9} \text { Non interest income }_{i, b}}+\varepsilon_{i}
\end{aligned}
$$

The dependent variable $\left(r_{i, c}\right)$ measures the distress of bank $i$ during the crisis period $c$ (2007Q4 to 2009Q4), ${ }^{3}$ while the regressors are computed as the average bank characteristics in the pre-crisis period $b$ (2003Q4 to 2007Q3). The use of average information from the pre-crisis period to forecast distress during the crisis serves to minimize endogeneity problems. A similar strategy has been adopted by Beltratti and Stulz (2012), Bekaert et al. (2014) and Demirgüç-Kunt et al. (2013). From an econometric perspective, these variables can be considered predetermined, which guarantees consistent forecasts. Whether these forecasting relationships can be also given a causal interpretation is of course a different matter. We will come back to this issue in section IV.

\footnotetext{
${ }^{3}$ Hence, our sample horizon excludes the period of tension in sovereign bond markets. This is because the spillover effects on the banking sector would distort our model and, thus, our final results. For instance, between 2009 and 2010, the yield for 10-year Greek government bonds increased from 5.2\% to 9.3\%, raising the spread with the government bonds of euro area counterparts from 110 basis points to 530 basis points. This also affected all the indicators of bank risk for Greek banks.
} 
The statistical sources used and brief description of the main variables included in our study are provided in Table I, while Table II shows the main descriptive statistics. Our initial dataset has more than 1,100 listed banks from 16 countries. ${ }^{4}$ It is a highly representative sample, as it covers around three-fourths of the total aggregate balance sheet of banks operating in the European Union and United States. The rest of this section describes in detail the construction of each variable.

\section{II.A Construction of bank risk variables}

The first purpose of our analysis is to identify the main determinants behind the accumulation of bank risk and its subsequent realization during the recent financial crisis. In order to obtain robust results it is crucial to recognize that during a crisis, the appearance of bank risk unfolds progressively and manifests itself in several and different dimensions. We employ six alternative measures of bank risk to capture these different dimensions and to ensure that our results do not depend on a narrow definition of bank risk. We believe that the use of all these measures is crucial to assess the validity of our findings. Indeed, a major possible reason for the contradictory findings of earlier empirical studies was probably related to the difficulty in finding sufficiently informative variables accounting for the different aspects of bank risk. ${ }^{5}$

i. Financial support - Our first measure describes whether an institution received any government support. The construction of this variable is based on the collection of information relating to the public rescue of banks via capital injections, the issuance of state-guaranteed bonds, or other governmentsponsored programmes. It is compiled from several sources, including the European Commission, central banks, the Bank for International Settlements, Bloomberg, and the websites of a number of government

\footnotetext{
${ }^{4}$ Namely: Austria, Belgium, Denmark, Germany, Greece, Finland, France, Ireland, Italy, Luxembourg, the Netherlands, Portugal, Spain, Sweden, the United Kingdom and the United States.

${ }^{5}$ Probably also an important reason for the diverging results is that for practical purposes, some of the variables that are able to capture some of the major dimensions of realized bank risk (such as central bank liquidity or government assistance) are not widely accessible to most researchers.
} 
institutions. ${ }^{6}$ The resulting dummy variable takes the value of one if public financial support was received during the crisis and zero otherwise. This is matched with information on listed banking groups (around 1,100 institutions) for which consolidated financial statements are available via Bloomberg (see below). ${ }^{7}$

ii. Systematic risk - Our second measure of bank risk describes the average (i.e. systematic) stock market reaction of each bank to movements on the overall stock market index. It is constructed using a simple capital asset pricing model, based on the following equation:

$$
R_{i, k, t}=\beta_{i, k, t^{*}} R_{m, k, t}+\varepsilon_{i, k, t}
$$

where $R_{i, k, t}$ is the daily logarithmic excess stock market returns for each bank $i$ from country $k$ at time $t ;{ }^{8} R_{m, k, t}$ is the daily logarithmic excess stock market returns from the broad stock market index $m$ for country $k$; and the term $\varepsilon_{i, k, t}$ is a bank-specific residual. To ensure comparability, we use the broad stock market index for each country available from Datastream. For each bank $i$, we calculate the systematic component $\beta_{i, k, t}$ by running separate regressions on daily data for every quarter $q$ from 2007Q4 to 2009Q4. We then calculate the average beta for each individual bank during the crisis period. Obviously this would reduce our original sample to only those banks which are listed and actively traded during our period of study (around 483 institutions).

iii. Systemic risk - Our third measure of bank risk broadly captures how exposed individual banks are to the occurrence of a systemic event. It measures tail dependence in the stock market returns of individual banks and equates the magnitude of tail dependence estimates as a measure of systemic risk. It is estimated via the marginal expected shortfall (MES) following the model by Acharya, Pedersen,

\footnotetext{
${ }^{6}$ For a comprehensive overview of the public measures in support of the financial sector see Stolz and Wedow (2010).

${ }^{7}$ We consider commercial or universal banks only. Hence foreign subsidiaries, investment banks, and non-bank financial institutions are not included in our sample.

${ }^{8}$ We calculate excess returns as the difference between stock market returns and the 10 -year government bond yield for the country concerned.
} 
Philippon and Richardson (2010) using a risk level of a=5\% calculated from daily data of individual banks' and countries' stock market equity returns from Datastream.

iv. Structural credit risk - Our fourth measure of bank risk is the expected default frequency $(E D F)$ and captures the constructed one-year ahead probability of default for each individual bank. It is computed by Moody’s KMV building on Merton's model to price corporate bond debt (Merton, 1974). The EDF value, expressed as a percentage, is calculated by combining banks' financial statements with stock market information and a proprietary default database. EDF developments are regularly used as an indicator by financial institutions, investors, central banks and regulators to monitor the health of the financial system.

v. Central bank liquidity - Our fifth measure of bank risk is based on confidential information on the liquidity provided to individual banks by the European Central Bank via the Eurosystem. It measures bank risk during a crisis by taking advantage of a change in the central bank's liquidity policy. Namely, in October 2008, following the collapse of Lehman Brothers, the central bank switched to a policy of full allotment and fixed rates which meant that euro area banks were able to get unlimited liquidity from the Eurosystem at the main refinancing rate provided they pledge adequate collateral. ${ }^{9}$ It is constructed as the overall liquidity position of each institution with the ECB. The liquidity amount is divided by total assets in order to make amounts comparable across institutions. Compared to other measures, this variable also accounts for liquidity risk, covering a key aspect of bank risk. By construction, this variable reduces our sample further as we limit it to the largest 83 euro area banking groups. They cover, nonetheless, more than $90 \%$ of the average liquidity provided by the Eurosystem. ${ }^{10}$

\footnotetext{
${ }^{9}$ Hence we restrict our results to the period of full allotment of liquidity provision by the European Central Bank (starting in October 2008) to avoid any distortions arising from changes in the central bank operational framework.

${ }^{10}$ We narrow our sample to the largest banking groups to ensure representativeness as in some countries many of the smallest banks often draw liquidity with the central bank indirectly via a larger institution.
} 
vi. Idiosyncratic risk- Our sixth measure describes the individual (i.e. non-systematic) dimension of bank risk constructed from the component of stock market movements of each bank $i$ which is unrelated to movements on the overall stock market index. It is constructed using a simple capital asset pricing model (see above) as the average of the quarterly non-overlapping standard deviations of the unexplained component $\varepsilon_{i, k, t}$ (or bank-specific residual) calculated for each bank $i$ from country $k$ using daily stock market prices during the crisis period (2007Q4 to 2009Q4).

\section{II.B Bank characteristics}

We next match information on average bank risk with data on bank characteristics from the pre-crisis period (2003Q4 to 2007Q3), using a dataset of consolidated quarterly financial statements obtained from Bloomberg. We also complete our database with information from other sources, such as Dealogic, BIS, Moody’s KMV, Bankscope and Datastream (see Table I).

The first variable characterizing the banks’ characteristics is size, measured as the average natural logarithm of total assets of the consolidated institution before the crisis. As in our literature review, we separate the other variables into four main groups.

Capital structure - We approximate bank capital by using a ratio of Tier I capital to total assets. Tier I capital is the regulatory term for core capital, essentially composed of common stocks and disclosed reserves. In line with Calem and Rob (1999) and the proposals made by the Basel Committee on Banking Supervision (2010), our measure of capital is interacted with a dummy indicator for banks with low capital ratios (below 6\%) to account for possible non-linear effects for less-capitalized banks.

Asset structure - A variable capturing an important aspect of the asset structure is the ratio of loans to total assets. It provides a summary indication of the extent to which a bank is involved in traditional lending activities. The other variable characterizing the asset structure is the amount of 
securitization activity. The data - based on Dealogic, an independent data provider - has been matched with balance sheet information from individual banks and then used to calculate the private securitization originated per quarter by each bank (i.e. percentage of bank credit sold on to the markets) as a proportion of total bank assets during the same period. ${ }^{11}$

Funding structure - The third group of regressors is concerned with the structure of on-balance sheet funding. It accounts for reliance on short-term wholesale funding, measured as the ratio of shortterm marketable securities to total assets, and more traditional retail deposit funding, also relative to total assets.

Income structure - We look at the two major income drivers of strategic importance to financial institutions. First, banks' lending strategy is measured as a bank’s average quarterly loan growth minus the national average. Second, we capture the degree of income diversification and the extent to which a bank has moved towards more volatile non-interest income sources by calculating their value as a percentage of total revenue.

\section{II.C Additional controls}

In our empirical analysis, we also include a number of additional controls. First, some of our specifications incorporate a group of macroeconomic controls that have been found to be related to banking crises in developed countries. These include changes in real housing prices, based on the country series constructed by the Bank for International Settlements (Borio and Drehmann, 2009), and changes in the broad stock market indices for non-financial corporations, as calculated by Datastream. Both of these asset price

\footnotetext{
${ }^{11}$ We look at individual deal-by-deal issuance patterns in the private securitization market. The advantage of using data on securitization activity from Dealogic is that the name of the originator, date of issuance and deal proceeds are registered. The sample includes public offerings of funded asset-backed securities (ABSs) as well as issues of cash flow (balance-sheet) collateralized debt obligations (CDOs). In other words, the securities included in the sample involve a transfer of funding from market investors to originators so that pure synthetic structures (such as synthetic CDOs which transfer credit risk only) and public securitization are not included.
} 
indices are demeaned from their long-term historical averages to capture abnormal changes in borrowers' collateral values. Second, we account for the impact on bank risk of potential corporate governance frictions arising from the bank ownership structure (Laeven and Levine, 2009; Erkens et al., 2012) with a Herfindahl index of ownership concentration of significant shareholders. It is calculated using information from Bankscope as the sum of the squared values of the percentage of equity held by each individual shareholder. Third, as a proxy for bank risk taking, we also consider banks, which underwent M\&A activities. The data include registered merger and acquisitions taking place in the European Union and the United States banking sector between 2002 and 2007. Individual deal-by-deal data on M\&A activity on financial firms are collected from the Thomson Reuters SDC Platinum database. Fourth, we account for bank risk aversion as revealed during a crisis using stock market returns from the previous crisis. This variable constructed using information from Datastream controls for the possibility that banks were accumulating certain risks that only materialized during a crisis.

\section{MAIN RESULTS}

This section discusses the main empirical findings of our analysis. We first present the results from probit and linear regression models applied to our six measures of bank risk. In the next subsections, we test the robustness of the results to the pre-crisis period and discuss the insights that can be derived from regression quantile estimates applied to systematic risk.

\section{III.A Baseline results}

Table III provides the estimates of the baseline specification for the six different measures of bank risk. The first column reports the results of the probit regression using as a measure of distress the dichotomous

variable indicating whether a bank received government support. Columns (II) to (VI) contain the 
coefficients of OLS regressions where distress is measured by systematic, systemic, structural credit, central bank liquidity and idiosyncratic risk as described in the previous section. ${ }^{12}$

The results are quite stark and strongly suggest that bank characteristics are highly predictive of bank risk particularly for the broader measures of bank risk (i.e. systemic, systematic, rescue and central bank liquidity). The only exception is that the predictive power of the idiosyncratic measures of bank risk as suggested by the very mild results obtained for the idiosyncratic risk variable.

With the exception the idiosyncratic risk variable, the results are also remarkably consistent across most columns, both in terms of sign and statistical significance. ${ }^{13}$ This already speaks to the robustness and validity of our empirical findings, as they do not depend on a particular definition of bank risk or specific samples (sample sizes vary widely in the six models due to different availability of data). Our results remain robust to the inclusion of additional controls (see next section).

Focusing on the results for the non-idiosyncratic measures of bank risk (columns I to V), bank size is actually the only variable whose sign changes across the models. It is positively related to measures of bank risk in the first three columns. The positive sign is consistent with the view that large banks were significantly riskier during the recent crisis. Large banks might have also been considered as "too big to fail”, thus inducing government to rescue them more often (Huang, et al., 2012; Demirgüç-Kunt and Huizinga, 2010; Tarashev et al., 2009). The apparently contradictory negative sign for size in column (V) is probably explained by the fact that the dependent variable is constructed as the ratio of central bank liquidity demand scaled by the size of the financial institution. Since size appears in the denominator of the dependent variable, higher size is mechanically associated with lower liquidity/size ratio. It could also

\footnotetext{
${ }^{12}$ In this table, we report only the estimates of the marginal effects of the probit model. The estimates and statistical significance of the coefficients of the probit model are fully consistent with the interpretation given to the marginal effects. Results are available upon request.

${ }^{13}$ It is important to bear in mind that the results in column (I) calculated via a probit are not directly comparable to those of the other columns.
} 
be that larger banks made less use of central bank liquidity in the euro area. It could be that larger banks were considered as too-big-to-fail by the financial markets and access to the short-term liquidity markets was more open for them than for smaller institutions requiring, as a result, less liquidity from the central bank. We next discuss the impact of the difference balance sheet structures.

Capital structure - A higher level of capital ex-ante generally tends to decrease the severity of bank distress during the crisis although this result does not hold for all definitions of bank risk. A novel and important finding of our analysis is that capital is far more important for undercapitalised banks, as indicated by the negative and highly statistically significant coefficients for most bank risk variables. This non-linear relationship between capital and risk is in line with Calem and Rob (1999), Perotti et al. (2011) and the proposals made by the Basel Committee on Banking Supervision in 2010 (BIS, 2010).

Asset structure - The ratios of loans to total assets are positively related to our measures of bank risk (Blaško and Sinkey, 2006). The negative sign for funded securitization suggests that banks, as originators, tended to use traditional securitization to off-load riskier loans from their balance sheets rather than as an instrument for taking on more risk. This is line with findings by Knaup and Wagner (2012) on the determinants of tail risks for US banks.

Funding structure - Consistent with our theoretical discussion, customer deposits tend to provide funding stability to banks and reduce the probability of a bank rescue. In contrast, the use of short-term marketable securities increases the probability of distress (Demirgüç-Kunt and Huizinga, 2010). It appears that those institutions more reliant on short-term market funding are more exposed to liquidity risk during the crisis, as it becomes problematic to roll over short-term debt to finance illiquid assets. These findings corroborate recent country evidence (Hahm, Shin and shin, 2013) and proposals to strengthen anticyclical 
liquidity regulations such as the use of liquidity charges (see for instance, Brunnermeier, Gorton and Krishnamurthy, 2012; Perotti and Suarez, 2011).

Income structure - Income generated through an aggressive expansion in loan growth in the runup to the crisis is generally associated with higher distress during the crisis, arguably due to a relaxation of credit standards and deterioration in the credit quality of the asset side of the balance sheet. This result emphasises the similarity of the recent crisis with macroeconomic evidence from earlier episodes of financial turmoil (Tornell and Westermann, 2002), raising the question of why remedial measures were not implemented at the supervisory level to smooth the credit cycle. It also informs the regulatory debate going forward (Reinhart and Rogoff, 2009). Results on non-interest income are more blurred and appear to be relevant for some of the specifications only.

\section{III.B Results before the crisis}

Table IV shows our baseline estimations using all available measures of risk and bank characteristics all calculated before the crisis takes place. Specifically, we also run our main estimations including information on the variables accounting for bank risk calculated as averages of quarterly data for individual banks during the 2006Q1 to 2006Q4 period. The variables accounting for bank characteristics are calculated as averages of quarterly data for individual banks during the 2003Q4 to 2005Q4 period. The idea is to ascertain whether some of the divergences in the findings of the empirical literature as well as the lack of action on the policy side could be linked to a lack of predictability of bank characteristics on bank risk before a crisis takes place.

Interestingly, the new estimations suggest that bank characteristics clearly predicted bank risk also prior to the crisis and were particularly relevant to forecast the systemic and systematic components of risk. Hence bank characteristics are good at predicting bank risk not only when a crisis takes place, but 
also before a crisis strikes thereby enhancing the practical implications and validity of our results. In this line also, as systemic risks is probably the dimension of risk with the strongest importance from a supervisory standpoint, our findings strongly suggests that supervisors would need to be particularly watchful at taming risks for banks with certain characteristics. In a way, our findings provide supportive evidence at the microeconometric level to the Reinhart and Rogoff's (2009) macroeconomic results.

An important practical implication of our findings is that banks with high systemic and systematic risk prior to the crisis would also be those institutions with relatively high materialized risk during the crisis. Figure II shows that that this was indeed the case. On the $\mathrm{X}$ axis, it shows the percentile values for the systematic risk variable during the pre-crisis period (2003Q4 to 2007Q3) including the 5\% (i.e. low systematic risk) and 95\% (i.e. high systematic risk) percentiles. On the $\mathrm{Y}$ axis, the diagram shows the 5\% (i.e. low systematic risk) and 95\% (i.e. high systematic risk) percentile values for the systematic risk variable for the crisis period (2007Q4 to 2009Q4). It clearly shows that those institutions with very high (low) systematic risk before the crisis were also well above (below) the average of systematic risk during the crisis.

\section{III.C Quantile results}

The next step when considering the relationship between bank characteristics and risk, is to see whether the role of certain characteristics is stronger (i.e. quantitatively and statistically more important) for the riskier banks (as materialized during the crisis). To do this we classify and rank banks during the crisis by quantiles according to their realized levels of bank risk.

By construction, probit and linear regression models give only a measure of the central tendency of the relationship between dependent and independent variables. This assumes that covariates affect only 
the location of the conditional distribution of $y$. Still, covariates can affect the conditional distribution in other ways, for instance, by affecting one tail but not the other. To give a concrete example, our baseline model shows that undercapitalized banks tend to be in greater distress during the crisis. But does this result necessarily hold for all banks - as the ordinary least squares, OLS, estimates would suggest - or do poorly capitalized banks disproportionately increase the risk for riskier banks relative to the less risky ones? We can obtain a more complete picture of the distributional dependence between the bank business model and bank risk by estimating quantile regressions.

Regression quantiles were first introduced by Koenker and Bassett (1978) and have been widely used ever since (for an introductory survey, see Koenker and Hallock, 2001). Our regression quantile estimates are obtained by minimizing the objective function $\min _{\beta} \sum_{i=1}^{N} \rho_{\tau}\left(r_{i, c}-X_{i, b} \beta_{\tau}\right)$. Here $r_{i, c}$ is the systematic risk variable for bank $i$ defined in section II.A, $X_{i, b}$ contains the same set of regressors as in equation (1), $N$ is the number of observations, $\rho_{\tau}(\lambda) \equiv \lambda(\tau-I(\lambda<0))$, $I$ is the indicator function whereby $I$ equals one if the expression in parenthesis is true and zero otherwise, and $\tau \in(0,1)$ is the probability associated with the quantile $c$. To facilitate a comparison with our baseline model, we use the same empirical specification.

We estimate the model using as dependent variable systematic risk. Results for the $10 \%, 25 \%$, $50 \%, 75 \%$ and $90 \%$ quantiles are presented in Table V. The last column in the Table reports the results of the equality test that the slope coefficients of the regression quantiles are all the same. Unsurprisingly, the signs of the regression quantile coefficients are coherent with the OLS results. For variables related to the 
asset and funding structure, we notice that the test results reported in the last column of the Table reject the null hypothesis that all regression quantile coefficients are equal. ${ }^{14}$

The results show that size, low levels of capital, low deposit base and excessive loan growth all unambiguously increase the level of distress during the crisis, irrespectively of which part of the risk distribution we are analyzing. Stronger capital levels and funding via bank deposits buttress bank stability particularly for the riskier banks. Fast paced loan growth and dependence on short-term market funding lead to progressively stronger impact on bank distress as the banks join the upper part of the risk distribution. This implies that the effects of certain bank characteristics become indeed stronger, as the intensity of the realization of bank risk becomes larger. This has the important policy implication that supervisors should be particularly alert by the effect of certain bank characteristics due to their impact on the group of riskier banks. As a result, early and more intense supervisory intensity would be warranted for banks with those characteristics.

\section{ROBUSTNESS}

Strictly speaking, the results presented in earlier sections are simple correlations and not causal relations, because of possible endogeneity concerns affecting our estimates. In fact, banks with a stronger risk attitude may be more likely to choose riskier business models, resulting in higher ex-post distress during times of crisis. In this case, the causality chain would run from risk to bank characteristics, rather than vice versa as implicit in our discussion so far. Tackling causality is generally not easy and our set up is no exception.

To start with, we would like to point out that our results remain of interest to policy makers, regardless of whether they can be given a causal interpretation. From a purely forecasting perspective,

\footnotetext{
${ }^{14}$ The test for the size variable does not reject the null hypothesis that the coefficient of size is equal across all the quantile specifications.
} 
since all dependent variables are predetermined, the policy maker can correctly infer that the banks more likely to be in trouble in most occasions in case of crisis are those with poor capital ratios, excessive loan growth, too much reliance on market funding and so on. Whether the more risky business model of the bank is driven by the risk preferences of its management is of additional interest (and can possibly be exploited by the policy maker), but does not subtract from the relevance of our results: banks with certain characteristics should be more carefully monitored by supervisors and eventually asked to reduce their overall level of risk.

These considerations notwithstanding, we address endogeneity concerns by including additional control variables in the main regressions (Tables VI and VII) and by using appropriate instruments. Table 6 reports the results of our robustness tests on our main bank risk specification. It includes additional controls to the baseline specification presented in Table III. It shows that the majority of our findings are robust to the inclusion of country dummies - columns (I), (III), (V), (VII) and (IX) - as well of additional variables capturing banks' profitability, and major macroeconomic variables (GDP, house prices and stock market returns) - (II), (IV), (VI) and (VIII). Probit estimates in columns (I) and (II) are qualitatively similar to our baseline specification. OLS regression results are also robust, although in this case some of the coefficients on non-interest income of the systematic risk regression become non-significant. Analogously, Table VII vouches for the robustness of the results for the estimations including information on bank risk for the pre-crisis period. We also account for the possible (lurking) effect of possible longlived risk-taking preferences of individual banks on our findings that affect both banks' business models and risk that only materializes in the event of a crisis. We do this by checking that our results remain 
robust to the inclusion of banks’ return during the previous crisis (as suggested in Fahlenbrach et al., 2012). ${ }^{15}$

An alternative strategy to tackle endogeneity concerns is to split the sample between banks which have been involved in mergers and acquisitions (M\&A), or alternatively between banks with a more or less dispersed ownership structure. The idea is that management and shareholders' risk preferences are unlikely to remain the same across these different groups. For instance, managers involved in M\&A activities may have higher risk propensity than the others. Similarly, a more concentrated ownership has a better control over management and is probably more likely to undertake riskier and possibly more profitable strategies (Laeven and Levine, 2009; Erkens et al., 2012). The results of Table VIII show that our findings remain robust to different groupings of banks, therefore adding further evidence in favor of causality running from balance sheet to risk. ${ }^{16}$

As a final robustness test - results available upon request - we ran an instrumental variable regression for systematic risk, using as instruments the average balance sheet variables of other banks in the country, ${ }^{17}$ as suggested by Laeven and Levine (2009). ${ }^{18}$ This instrument captures the industry and country factors driving our regressors and should in general not be affected by the risk propensity of the single bank.

\footnotetext{
${ }^{15}$ Following Fahlenbrach et al (2012), the previous crisis return was calculated for the 1998 crisis. We identified the lowest stock price level between the 3rd of August and 31st of December 1998 then using daily return data we calculate the return from the 3rd of August to the minimum stock price level of the crisis period in 1998. Results are available upon request.

${ }^{16}$ The only exception is the size variable for banks involved in M\&A activities. This may be explained by the fact that those banks may have been forced to deep restructuring and have been able to exploit economies of scale of the newly created entity.

17 That is, we define the instrument as:$$
\tilde{x}_{i b}^{c} \equiv(\# j \in \text { country } c ; j \neq i)^{-1} \sum_{j \in \operatorname{country} c ; j \neq i} x_{j b}
$$

${ }^{18}$ For US banks we have considered a breakdown at state level.
} 


\section{CONCLUSION}

In the years prior to the 2007-2009 crisis, most forward-looking indicators of bank risk clustered and suggested an unusually benign outlook. Hence was the ex-post realization of bank risk during the crisis largely unexpected? We show that in the run-up to the crisis different bank characteristics can explain a significant portion of the cross-sectional realization of bank risk during the 2007-2009 financial crisis. Banks with unstable funding, aggressive credit expansion, large size and low levels of capital in the years before the crisis experienced more troubles after Lehman's default. We also show that the impact of these characteristics consistently predicts several dimensions of bank risk but not he idiosyncratic dimension of bank risk. We also find that those bank characteristics that were related to risk as materialized during the crisis were also useful to predict bank risk before the financial crisis erupted. We finally show that the impact of the balance sheet variables is non-linear: Our regression quantile analysis reveals how dependence on less stable balance sheet funding, more aggressive growth strategy and lower capital are conducive to more realized risk, in particular for the group of riskier institutions. We subject our results to a battery of robustness tests. 


\section{REFERENCES}

Acharya, V., Pedersen L.H., Philippon T. and Richardson M.P. (2010), “Measuring Systemic Risk”, American Finance Association 2011 Denver Meetings Paper.

Bank for International Settlements (2010), "The Group of Governors and Heads of Supervision Reach Broad Agreement on Basel Committee Capital and Liquidity Reform Package”, Basel Committee on Banking Supervision.

Bekaert, G., Ehrmann M., Fratzscher M. and Mehl A. (2014), “Global Crises and Equity Market Contagion”, Journal of Finance 69 (6), pp. 2597-2640.

Beltratti, A. and Stulz R.M. (2012), "Why Did Some Banks Perform Better During the Credit Crisis? A Crosscountry Study of the Impact of Governance and Regulation”, Journal of Financial Economics 105 (1), pp. 117.

Berger, A. and Bouwman C. (2013), “How Does Capital Affect Bank Performance During Financial Crises?”, Journal of Financial Economics 109 (1), pp. 146-176.

Berger, A., Molyneux P. and Wilson J. (2015), Handbook of Banking, Oxford University Press, Second Edition.

Bhattacharya, S. and Thakor A.V. (1993), “Contemporary Banking Theory”, Journal of Financial Intermediation 3 (1), pp. 2-50.

Blaško, M. and Sinkey J.F. (2006), “Bank Asset Structure, Real Estate Lending, and Risk-taking”, The Quarterly Review of Economics and Finance 46, pp. 53-81.

Borio, C. and Drehmann M. (2009), “Assessing the Risk of Banking Crises - Revisited”, Bank for International Settlements Quarterly Review, March.

Brunnermeier, M., Gorton G. and Krishnamurthy A. (2012), “Liquidity Mismatch Measurement”, NBER Chapters in Risk Topography: Systemic Risk and Macro Modelling, National Bureau of Economic Research.

Brunnermeier, M., Dong G. and Palia D. (2012), “Banks’ Non-Interest Income and Systemic Risk”, American Finance Association 2012 Chicago Meetings Paper.

Calem, P. and Rob R. (1999), “The Impact of Capital-Based Regulation on Bank Risk-Taking”, Journal of Financial Intermediation 8 (4), pp. 317-352.

Calomiris, C. and Kahn C. (1991), “The Role of Demandable Debt in Structuring Optimal Banking Arrangements”, American Economic Review 81 (3), pp. 497-513.

Campbell, J.Y., Lettau M., Malkiel B.G. and Xu Y. (2001), “Have Individual Stocks Become More Volatile?”, Journal of Finance 56 (1), pp. 1-43.

Cebenoyan, A. and Strahan P. (2004), "Risk Management, Capital Structure and Lending at Banks”, Journal of Banking and Finance 28, pp. 19-43.

De Jonghe, O. (2010), “Back to the Basics in Banking? A Micro-analysis of Banking System Stability”, Journal of Financial Intermediation 19 (3), pp. 387-417.

Delis, M.D. and Staikouras P.K. (2011), “Supervisory Effectiveness and Bank Risk”, Review of Finance 15 (3), pp. 511-543.

Demirgüç-Kunt, A. and Huizinga H.P. (2010), "Bank Activity and Funding Strategies: The Impact on Risk and Return”, Journal of Financial Economics 98 (3), pp. 626-650.

Demirgüç-Kunt, A., Detragiache E. and Merrouche O. (2013), "Bank Capital: Lessons from the Financial Crisis”, Journal of Money, Credit and Banking 45 (6), pp. 1147-1164. 
Diamond, D.W. and Rajan R.G. (2001), "Liquidity Risk, Liquidity Creation, and Financial Fragility: A Theory of Banking”, Journal of Political Economy 109, pp. 287-327.

Erkens, D., Hung M. and Matos P. (2012), “Corporate Governance in the 2007-2008 Financial Crisis: Evidence from Financial Institutions Worldwide”, Journal of Corporate Finance 18 (2), pp.389-411.

Fahlenbrach, R., Prilmeier R. and Stulz R.M. (2012), "This Time is the Same: Using Bank Performance in 1998 to Explain Bank Performance During the Recent Financial Crisis”, Journal of Finance 67, pp. 2139-2185.

Foos, D., Norden L. and Weber M. (2010), “Loan Growth and Riskiness of Banks”, Journal of Banking and Finance 34 (12), pp. 2929-2940.

Freixas, X. and Rochet J.C. (2008), Microeconomics of banking (2nd edition), MIT Press.

Gorton, G. and Metrick A. (2012), “Securitized Banking and the Run on Repo”, Journal of Financial Economics 104 (3), pp. 425-451.

Gorton, G. (2012), Misunderstanding Financial Crisis: Why don't we See Them Coming, Oxford University Press.

Hahm, J.H., Shin H. and Shin K. (2013), “Non-Core Bank Liabilities and Financial Vulnerability”, Journal of Money, Credit and Banking 45 (8), pp. 3-36, 08.

Haldane, A and Madouros V. (2012), “The Dog and the Frisbee”, speech presented at the Federal Reserve Bank of Kansas City’s 36th economic policy symposium “The Changing Policy Landscape”, Jackson Hole, Wyoming.

Huang, X., Zhou H. and Zhu H. (2012), “Systemic Risk Contributions”, Journal of Financial Services Research 42 (1), pp. 55-83.

Huang, R. and Ratnovski L. (2011), “The Dark Side of Bank Wholesale Funding”, Journal of Financial Intermediation 20 (2), pp. 248-263.

IMF (2009), Global Financial Stability Review, International Monetary Fund, April.

Jensen, M.C. and Meckling W.H. (1976), “Theory of the Firm: Managerial Behavior, Agency Costs and Ownership Structure”, Journal of Financial Economics 3 (4), pp. 305-360.

Keys, B., Mukherjee T., Seru A. and Vig V. (2010), "Did Securitization Lead to Lax Screening? Evidence from Subprime Loans”, Quarterly Journal of Economics 125, pp. 307-362.

Kim, M., Kliger D. and Vale B. (2003), “Estimating Switching Costs: the Case of Banking”, Journal of Financial Intermediation 12 (1), pp. 25-56.

Knaup, M. and Wagner W. (2012), “Forward-Looking Tail Risk Exposures at U.S. Bank Holding Companies”, Journal of Financial Services Research 42 (1), pp. 35-54.

Koenker, R. and Bassett G. (1978), “Regression Quantiles”, Econometrica 46 (1), pp. 33-50.

Koenker, R. and Hallock K.F. (2001), “Quantile Regression”, Journal of Economic Perspectives 15 (4), pp. 143156.

Laeven, L. and Levine R. (2009), “Bank Governance, Regulation and Risk-taking”, Journal of Financial Economics 93 (2), pp. 259-275.

Laeven, L. and Majnoni G. (2003), “Loan Loss Provisioning and Economic Slowdowns: Too Much, Too Late?”, Journal of Financial Intermediation 12 (2), pp. 178-197.

Laeven, L., Ratnovski L. and Tong H. (2014), “Bank Size and Systemic Risk”, International Monetary Fund Staff Discussion Notes 14 (4).

Marques-Ibanez, D. and Scheicher M. (2010), “Securitization: Instruments and Implications”, in A. Berger, P. Molyneux and J. Wilson (eds.), The Oxford Handbook of Banking, pp. 530-555. 
Merton, R.C. (1974), “On the Pricing of Corporate Debt: The Risk Structure of Interest Rates”, Journal of Finance 29 (2), pp. 449-470.

Mian, A. and Sufi A. (2009), "The Consequences of Mortgage Credit Expansion: Evidence From the U.S. Mortgage Default Crisis”, Quarterly Journal of Economics 124, pp. 1449-1496.

Nijskens, R. and Wagner W. (2011), “Credit Risk Transfer Activities and Systemic Risk: How Banks Became Less Risky Individually but Posed Greater Risks to the Financial System at the Same Time”, Journal of Banking and Finance 35 (6), pp. 1391-1398.

Perotti, E., Ratnovski L. and Vlahu R. (2011), “Capital Regulation and Tail Risk”, International Journal of Central Banking 7(4), pp. 123-163,

Perotti, E. and Suarez J. (2011), “A Pigovian Approach to Liquidity Regulation”, International Journal of Central Banking 7 (4), pp. 3-41.

Reinhart, C.M. and Rogoff K.S. (2009), This Time Is Different: Eight Centuries of Financial Folly, Princeton University Press.

Shin, H.S. (2009), “Securitisation and Financial Stability”, Economic Journal 119 (536), pp. 309-332.

Shleifer, A. and Vishny R.W. (2010), “Unstable Banking”, Journal of Financial Economics 97 (3), pp. 306-318.

Stiroh, K.J. (2015), "Diversification in Banking”, in A. Berger, P. Molyneux and J. Wilson (eds.), The Oxford Handbook of Banking pp. 146-171.

Stolz, S. and Wedow M. (2010), "Extraordinary Measures in Extraordinary Times - Public Measures in Support of the Financial Sector in the EU and the United States”, European Central Bank Occasional Paper Series 117.

Tarashev, N., Borio C. and Tsatsaronis K. (2009), “The Systemic Importance of Financial Institutions”, Bank for International Settlements Quarterly Review, September.

Tornell, A. and Westermann F. (2002), “Boom-Bust Cycles in Middle Income Countries: Facts and Explanation”, NBER Working Paper 9219.

Wu, D., Yang J. and Hong H. (2011), “Securitization and Banks’ Equity Risk”, Journal of Financial Services Research 39 (3), pp. 95-117. 


\section{Figure I}

\section{Box plot distribution of the stock market returns of individual banks}

The diagram below shows the cross-sectional distribution of stock market returns for the combined sample of listed European and US banks included in our exercise for the pre-crisis (2003Q4 to 2007Q3) and crisis (2007Q4 to 2009Q4) periods. It is based on monthly stock market prices obtained from Datastream. For the pre-crisis and crisis periods, for each banks we calculate the $10 \%$, $25 \%, 50 \%, 75 \%$ and $90 \%$ quantiles of the distribution of average stock market returns. The "box plot" consists of a "box" that moves from the first to the third quartile (Q1 to Q3) of the distribution of stock market returns for the pre-crisis (2003Q4 to 2007Q3) and crisis (2007Q4 to 2009Q4) periods. Within the box itself, the thick horizontal line represents the median. The area below the bottom whisker moves from the $25 \%$ to the $10 \%$ quantile, while the area above the top whisker moves from the $75 \%$ to the $90 \%$ quantile of the distribution.

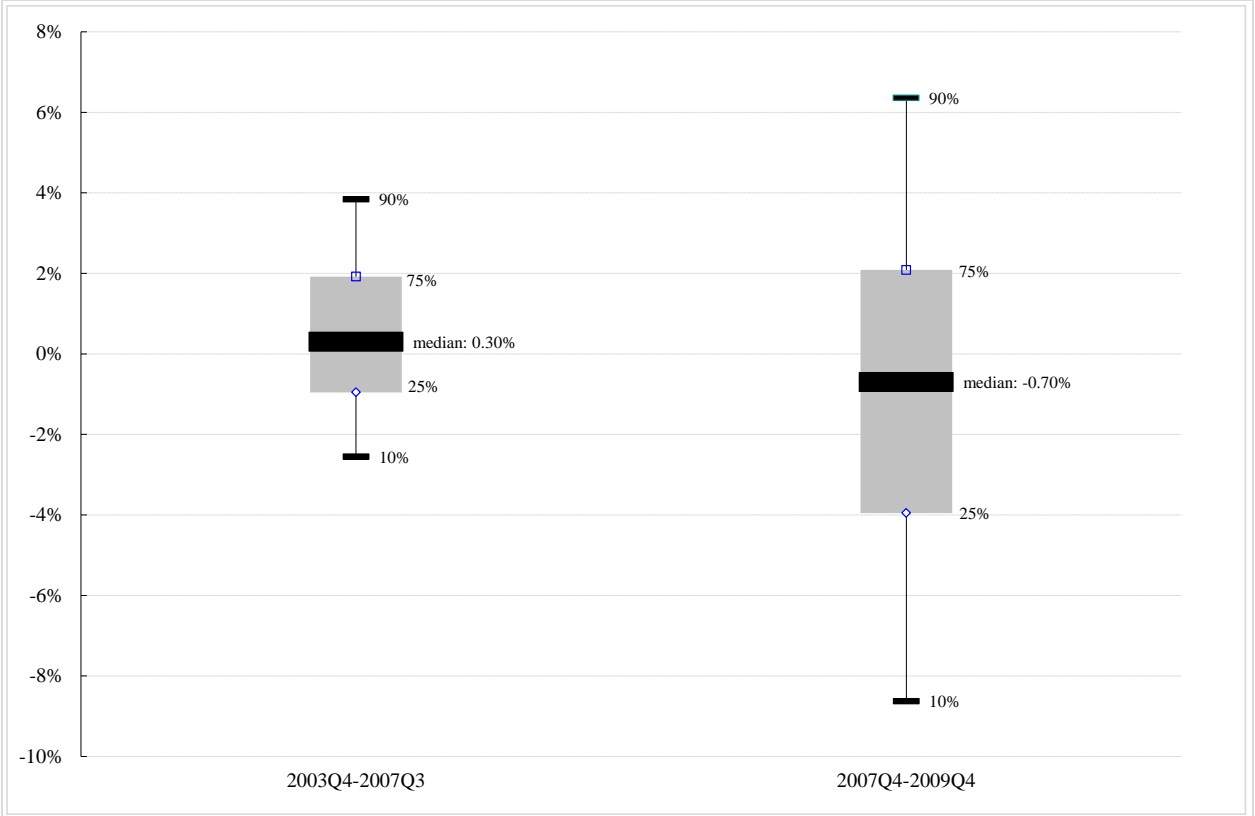


Figure II

\section{Scatter plots of the systematic risk levels for the pre-}

\section{and post-crisis periods}

On the $\mathrm{X}$ axis, the diagram below shows the 5 (i.e. low systematic risk) and 95 (i.e. high systematic risk) percentile values for the systematic risk variable during the pre-crisis period (2003Q4 to 2007Q3). Systematic risk is calculated as the average of the quarterly non-overlapping betas in a capital asset pricing model calculated for each bank $\mathrm{i}$ on country $\mathrm{j}$ using daily stock market data using stock market prices obtained from Datastream for the listed European and US banks included in our sample. On the Y axis, the diagram shows the 5 (i.e. low systematic risk) and 95\% (i.e. high systematic risk) percentile values for the systematic risk variable for the crisis period (2007Q4 to 2009Q4).

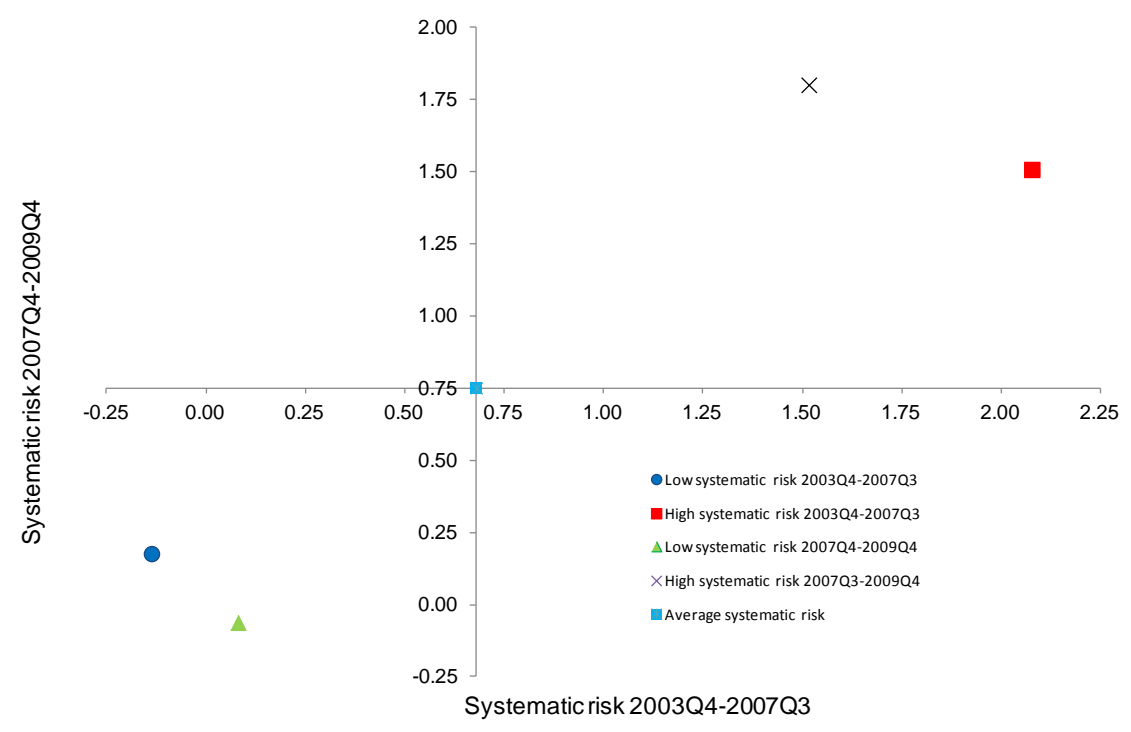




\section{Table I \\ Summary Statistics}

This table reports summary statistics for the primary variables used in this study (see Section II and Table I for further details on the variables). Variables accounting for bank risk are calculated using the average values for each bank during the crisis period (2007Q4 to 2009Q4) except for the variable accounting for central bank liquidity. The latter is constructed only for the period of full liquidity allotment by the European Central Bank (2009Q1 to 2009Q4). The variables accounting for size, capital structure, asset structure, funding structure, income structure, profitability and corporate governance are calculated from the averages of quarterly data for individual banks for the pre-crisis period (2003Q4 to 2007Q3). GDP growth, house prices and stock market are calculated as country averages from quarterly data during the pre-crisis period already mentioned.

\begin{tabular}{|c|c|c|}
\hline Variable & Source & Description \\
\hline \multicolumn{3}{|c|}{ Panel A: Bank risk variables } \\
\hline Financial support & $\begin{array}{l}\text { European Commission, national central } \\
\text { banks, Bank for International Settlements, } \\
\text { other public institutions and Bloomberg }\end{array}$ & $\begin{array}{l}\text { Binary variable - with a value of } 1 \text { if public financial support was received durin } \\
\text { the crisis period (2007Q4 to 2009Q4) and } 0 \text {, if otherwise. }\end{array}$ \\
\hline Systematic risk & Datastream and authors' calculation & $\begin{array}{l}\text { Average of the quarterly non-overlapping betas in a capital asset pricing model } \\
\text { constructed for each bank i on country j using daily stock market data calculated } \\
\text { during the crisis (2007Q4 to 2009Q4) and non-crisis (2003Q4 to 2007Q3) periods. }\end{array}$ \\
\hline Systemic risk & $\begin{array}{l}\text { Authors' calculation following Acharya et al. } \\
\text { (2010) }\end{array}$ & $\begin{array}{l}\text { Estimated via the marginal expected shortfall (MES) following Acharya et al. } \\
\text { (2010), using a risk level of } \alpha=5 \% \text { calculated for the crisis (2007Q4 to 2009Q4) } \\
\text { and non-crisis (2003Q4 to 2007Q3) periods from daily data of individual banks' } \\
\text { and countries' stock market equity returns. }\end{array}$ \\
\hline $\begin{array}{l}\text { Structural credit risk } \\
(E D F)\end{array}$ & Moody's KMV & $\begin{array}{l}\text { One-year ahead probability of default. It is computed by Moody's KMV building } \\
\text { on Merton's model to price corporate bond debt (Merton, 1974). The EDF value } \\
\text { expressed as a percentage, is calculated by combining banks' financial statements } \\
\text { with stock market information and a proprietary default database. We calculate the } \\
\text { average of quarterly data for the crisis (2007Q4 to 2009Q4) and non-crisis } \\
\text { (2003Q4 to 2007Q3) periods. }\end{array}$ \\
\hline Central bank liquidity & European Central Bank & $\begin{array}{l}\text { Average of the liquidity received from the ECB to total assets * } 100 \text { during the } \\
\text { period of full liquidity allotment from the central bank (2009Q1 to 2009Q4). }\end{array}$ \\
\hline Idiosyncratic risk1 & Authors' calculation & $\begin{array}{l}\text { Average of the quarterly non-overlapping standard deviations of the unexplained } \\
\text { component in a capital asset pricing model calculated for each bank i on country } \\
\text { using daily stock market prices calculated during the crisis (2007Q4 to 2009Q4) } \\
\text { and non-crisis (2003Q4 to 200Q3) period. }\end{array}$ \\
\hline Idiosyncratic risk2 & $\begin{array}{l}\text { Authors' calculation following Campbell et al. } \\
\text { (2001) }\end{array}$ & $\begin{array}{l}\text { Following Campbell et al. (2001) we decomposed the realized volatility of stoch } \\
\text { market prices for each bank i into three components: market wide, banking } \\
\text { industry-specific, and bank-specific volatility. The Idiosyncratic risk2 variable is } \\
\text { calculated for every bank i quarterly as the bank specific component of the realize } \\
\text { volatility. We calculate the average of quarterly data for the crisis (2007Q4 to } \\
\text { 2009Q4) and non-crisis (2003Q4 to 2007Q3) periods. }\end{array}$ \\
\hline
\end{tabular}

Panel B: Balance sheet variables

\begin{tabular}{|c|c|c|}
\hline Size & Bloomberg & Average of the quarterly logarithm of total assets (USD millions). \\
\hline \multicolumn{3}{|l|}{ Capital structure } \\
\hline Capital & Bloomberg & $\begin{array}{l}\text { Average of the quarterly tier I capital to total assets' ratio * } 100 \text { during the pre-crisis } \\
\text { period (2003Q4 to 2007Q3). }\end{array}$ \\
\hline Undercapitalised & Authors' calculation & $\begin{array}{l}\text { Average of the quarterly interaction between tier I capital and a low capital dummy } \\
\text { variable (for which } 1 \text { indicates a bank with a Tier I ratio below 6\%) for the pre- } \\
\text { crisis period (2003Q4 to 2007Q3). }\end{array}$ \\
\hline \multicolumn{3}{|l|}{ Asset structure } \\
\hline Loans to total assets & Bloomberg & $\begin{array}{l}\text { Average of the quarterly total loans to total assets' ratio * } 100 \text { during the pre-crisis } \\
\text { period (2003Q4 to 2007Q3). }\end{array}$ \\
\hline Securitization & DCM Analytics Dealogic & $\begin{array}{l}\text { Average of the quarterly total securitization flow to total assets' ratio * } 100 \text { of each } \\
\text { originating bank during the pre-crisis period (2003Q4 to 2007Q3). }\end{array}$ \\
\hline \multicolumn{3}{|l|}{ Funding structure } \\
\hline $\begin{array}{l}\text { Short-term market } \\
\text { funding }\end{array}$ & Bloomberg & $\begin{array}{l}\text { Average of the quarterly short-term market debt (i.e. less than } 2 \text { years) to total } \\
\text { assets' ratio * } 100 \text { during the pre-crisis period (2003Q4 to 2007Q3). }\end{array}$ \\
\hline Deposit funding & Bloomberg & $\begin{array}{l}\text { Average of the quarterly customer deposits to total assets' ratio * } 100 \text { during the } \\
\text { pre-crisis period (2003Q4 to 2007Q3). }\end{array}$ \\
\hline Excessive loan growth & Authors' calculation & $\begin{array}{l}\text { Average of the quarterly individual bank lending growth minus the average loan } \\
\text { growth of all banks in each country over that quarter during the pre-crisis period }\end{array}$ \\
\hline Non-interest income & Bloomberg & $\begin{array}{l}\text { Average of the quarterly non-interest income to total revenues' ratio * } 100 \text { during } \\
\text { the pre-crisis period (2003Q4 to 2007Q3). }\end{array}$ \\
\hline \multicolumn{3}{|c|}{ Panel C: Control variables } \\
\hline Profitability & Bloomberg & $\begin{array}{l}\text { Average of the quarterly net income to total assets' ratio * } 100 \text { during the pre-crisis } \\
\text { period (2003Q4 to 2007Q3). }\end{array}$ \\
\hline GDP growth & Bank for International Settlements & $\begin{array}{l}\text { Average of the quarterly changes in real GDP during the pre-crisis period (2003Q4 } \\
\text { to 2007Q3). }\end{array}$ \\
\hline House prices & Bank for International Settlements & $\begin{array}{l}\text { Average of the quarterly changes in real housing prices during the pre-crisis period } \\
\text { (2003Q4 to 2007Q3) demeaned from their long-term historical averages (prior } 20 \\
\text { years). }\end{array}$ \\
\hline Stock market & Datastream & $\begin{array}{l}\text { Average of the quarterly changes in broad country's non-financial corporations } \\
\text { stock market indices constructed by Datastream during the pre-crisis period } \\
\text { (2003Q4 to 2007Q3) de-meaned from their long-term historical averages (prior } 20 \\
\text { years). }\end{array}$ \\
\hline Corporate governance & Thomson Reuters and authors' calculation & $\begin{array}{l}\text { Calculated as the average of the yearly sum of the squares of the percentages of the } \\
\text { ownership's shares controlled by each shareholder on each individual bank during } \\
\text { the pre-crisis period (2003Q4 to 2007Q3). }\end{array}$ \\
\hline Dispersed ownerships & Thomson Reuters and authors' calculation & $\begin{array}{l}\text { Binary variable - with a value of } 1 \text { if the average ownership concentration is less } \\
\text { than } 10 \% \text { during the pre-crisis period (2003Q4 to 2007Q3) and } 0 \text {, if otherwise. }\end{array}$ \\
\hline M\&A Involvement & Thomson Reuters - SDC Platinum database & $\begin{array}{l}\text { Binary variable - with a value of } 1 \text { if the institution was involved in one or more } \\
\text { mergers and acquisitions (M\&A) during the pre-crisis period (2003Q4 to 2007Q3) } \\
\text { and 0, if otherwise. }\end{array}$ \\
\hline
\end{tabular}


Table II

Summary Statistics

This table reports summary statistics for the primary variables used in this study (see Section II and Table I for further details on the variables). Variables accounting for bank risk are calculated using the average values for each bank during the crisis period (2007Q4 to 2009Q4) except for the variable accounting for central bank liquidity. The latter is constructed only for the period of full liquidity allotment by the European Central Bank (2009Q1 to 2009Q4). The variables accounting for size, capital structure, asset structure, funding structure, income structure, profitability and corporate governance are calculated from the averages of quarterly data for individual banks for the pre-crisis period (2003Q4 to 2007Q3). GDP growth, house prices and stock market are calculated as country averages from quarterly data during the pre-crisis period already mentioned.

\begin{tabular}{|c|c|c|c|c|c|c|}
\hline Variables & $\mathbf{N}$ & Average & Median & $\begin{array}{r}\text { Standard } \\
\text { Deviation }\end{array}$ & Minimum & Maximum \\
\hline \multicolumn{7}{|l|}{ Panel A: Bank Risk } \\
\hline Financial support & 852 & 0.26 & 0.00 & 0.44 & 0.00 & 1.00 \\
\hline Systematic risk & 483 & 0.70 & 0.47 & 0.60 & -0.33 & 2.29 \\
\hline Systemic risk & 483 & 3.25 & 2.97 & 2.60 & 2.94 & 15.97 \\
\hline Structural credit risk (EDF) & 547 & 0.93 & 0.32 & 2.30 & 0.01 & 27.78 \\
\hline Central bank liquidity & 84 & 2.66 & 1.24 & 3.45 & 0.00 & 18.87 \\
\hline Idiosyncratic risk1 & 483 & 0.00 & 0.00 & 0.01 & -0.13 & 0.02 \\
\hline Idiosyncratic risk2 & 483 & 0.21 & 0.12 & 0.54 & 0.00 & 11.06 \\
\hline \multicolumn{7}{|c|}{ Panel B: Balance Sheet Variables } \\
\hline Size & 852 & 7.29 & 6.62 & 2.07 & 1.57 & 13.98 \\
\hline \multicolumn{7}{|l|}{ Capital Structure } \\
\hline Capital & 852 & 9.63 & 8.82 & 5.62 & 1.62 & 72.14 \\
\hline Undercapitalised & 852 & 0.52 & 0.00 & 1.47 & 0.00 & 5.98 \\
\hline \multicolumn{7}{|l|}{ Asset Structure } \\
\hline Loans to total assets & 852 & 65.53 & 68.17 & 15.21 & 0.96 & 92.92 \\
\hline Securitization & 852 & 0.10 & 0.00 & 0.84 & 0.00 & 19.68 \\
\hline \multicolumn{7}{|l|}{ Funding Structure } \\
\hline Short-term market funding & 852 & 19.33 & 17.03 & 12.97 & 1.00 & 90.00 \\
\hline Deposit funding & 852 & 70.78 & 74.91 & 15.13 & 7.05 & 90.09 \\
\hline \multicolumn{7}{|l|}{ Income Structure } \\
\hline Excessive loan growth & 483 & 6.27 & 5.75 & 2.33 & -2.12 & 13.27 \\
\hline Non-interest income & 483 & 20.01 & 16.53 & 14.24 & 2.05 & 97.02 \\
\hline \multicolumn{7}{|l|}{ Panel C: Control Variables } \\
\hline Profitability & 852 & 0.99 & 0.96 & 0.75 & -6.24 & 8.70 \\
\hline GDP growth & 852 & 1.29 & 1.34 & 0.20 & 0.58 & 2.09 \\
\hline House prices & 852 & 1.19 & 1.33 & 0.58 & -1.62 & 2.42 \\
\hline Stock market & 852 & 1.56 & 1.36 & 0.63 & -0.19 & 5.57 \\
\hline Dispersed ownerships & 684 & 0.84 & 1.00 & 0.36 & 0.00 & 1.00 \\
\hline M\&A Involvement & 852 & 0.24 & 0.00 & 0.43 & 0.00 & 1.00 \\
\hline
\end{tabular}


Table III

Effects of Balance sheet Structures on Bank Risk

This table reports the results from our bank risk regressions. Column (I) reports the results of the probit regression using government support as a measure of bank risk. Columns (II) to (VII) contain the coefficients of OLS regressions where bank risk is measured as systematic risk, systemic risk, structural credit risk, central bank liquidity and two measures of idiosyncratic risk. See Section II for further details and Table I for variables' definitions. The dependent variables are calculated as averages of quarterly data for individual banks during the pre-crisis period (2007Q4 to 2009Q4) except for the variable accounting for central bank liquidity. The latter is constructed only for the period of full liquidity allotment by the European Central Bank (2009Q1 to 2009Q4). The variables accounting for size, capital structure, asset structure, funding structure and income structure are calculated from the averages of quarterly data for individual banks during the pre-crisis period (2003Q4 to 2007Q3). *, ** and *** indicate statistical significance at the $10 \%, 5 \%$ and $1 \%$ levels, respectively.

\begin{tabular}{|c|c|c|c|c|c|c|c|c|}
\hline & & \multicolumn{7}{|c|}{ Dependent Variable: Measures of Bank Risk } \\
\hline & & Rescue & $\begin{array}{r}\text { Systematic } \\
\text { risk }\end{array}$ & $\begin{array}{l}\text { Systemic } \\
\text { risk }\end{array}$ & $\begin{array}{l}\text { Structural } \\
\text { credit risk }\end{array}$ & $\begin{array}{c}\text { Central } \\
\text { bank } \\
\text { liquidity }\end{array}$ & $\begin{array}{r}\text { Idiosyncratic } \\
\text { risk1 }\end{array}$ & $\begin{array}{r}\text { Idiosyncratic } \\
\text { risk2 }\end{array}$ \\
\hline & & (I) & (II) & (III) & (IV) & (V) & (VI) & (VII) \\
\hline \multicolumn{2}{|r|}{ Size } & $\begin{array}{l}0.0409 * * * \\
(0.003)\end{array}$ & $\begin{array}{l}0.1090 \text { *** } \\
(0.032)\end{array}$ & $\begin{array}{l}0.6949 * * * \\
(0.134)\end{array}$ & $\begin{array}{r}-0.0358 \\
(0.109) \\
\end{array}$ & $\begin{array}{l}-0.2979 * * * \\
(0.023)\end{array}$ & $\begin{array}{l}0.0006 * * * \\
(0.000)\end{array}$ & $\begin{array}{l}0.0948 * * \\
(0.042)\end{array}$ \\
\hline \multirow{2}{*}{ 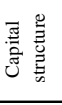 } & Capital & $\begin{array}{l}-0.0207 * * * \\
(0.001)\end{array}$ & $\begin{array}{l}-0.0097 \\
(0.007)\end{array}$ & $\begin{array}{l}-0.0349 \\
(0.036)\end{array}$ & $\begin{array}{l}-0.0638 * * \\
(0.025)\end{array}$ & $\begin{array}{l}-0.1814 \text { *** } \\
(0.053)\end{array}$ & $\begin{array}{l}-0.0001 \\
(0.000)\end{array}$ & $\begin{array}{r}-0.0002 \\
(0.011)\end{array}$ \\
\hline & Undercapitalized & $\begin{array}{l}-0.0415 * * * \\
(0.008)\end{array}$ & $\begin{array}{l}-0.0811 * * * \\
(0.017)\end{array}$ & $\begin{array}{l}-0.1116 * * * \\
(0.040)\end{array}$ & $\begin{array}{l}-0.0969 * \\
(0.057)\end{array}$ & $\begin{array}{r}-0.0097 \\
(0.020)\end{array}$ & $\begin{array}{l}-0.0008 * * * \\
(0.000)\end{array}$ & $\begin{array}{r}-0.0051 \\
(0.019) \\
\end{array}$ \\
\hline \multirow{2}{*}{ 总 } & Loans to total assets & $\begin{array}{l}0.0047 \text { *** } \\
(0.001)\end{array}$ & $\begin{array}{l}0.0061^{* * *} \\
(0.002)\end{array}$ & $\begin{array}{l}0.0356 * * * \\
(0.013)\end{array}$ & $\begin{array}{l}0.0255 \text { ** } \\
(0.011)\end{array}$ & $\begin{array}{l}0.0781 \text { *** } \\
(0.004)\end{array}$ & $\begin{array}{r}0.0000 \\
(0.001)\end{array}$ & $\begin{array}{l}-0.0028 \\
(0.003)\end{array}$ \\
\hline & Securitization & $\begin{array}{l}-0.0103 * * * \\
(0.001)\end{array}$ & $\begin{array}{l}-0.2076 * * * \\
(0.054)\end{array}$ & $\begin{array}{l}-0.5671 * * * \\
(0.189)\end{array}$ & $\begin{array}{l}-0.2427 * * \\
(0.099)\end{array}$ & $\begin{array}{l}-0.6012 * * * \\
(0.143)\end{array}$ & $\begin{array}{l}0.0005 * * * \\
(0.000)\end{array}$ & $\begin{array}{r}0.0566 \\
(0.071) \\
\end{array}$ \\
\hline \multirow{2}{*}{ 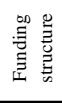 } & Short-term market funding & $\begin{array}{l}0.0071 \text { *** } \\
(0.001)\end{array}$ & $\begin{array}{l}0.0097 \text { *** } \\
(0.003)\end{array}$ & $\begin{array}{l}0.0494 * \\
(0.025)\end{array}$ & $\begin{array}{l}0.0249 * \\
(0.013)\end{array}$ & $\begin{array}{l}0.1483 \text { *** } \\
(0.006)\end{array}$ & $\begin{array}{l}0.0001 * \\
(0.000)\end{array}$ & $\begin{array}{l}-0.0021 \\
(0.004)\end{array}$ \\
\hline & Deposit funding & $\begin{array}{l}-0.0103 * * * \\
(0.001)\end{array}$ & $\begin{array}{l}-0.0201 * * * \\
(0.003)\end{array}$ & $\begin{array}{l}-0.0655 * * * \\
(0.016)\end{array}$ & $\begin{array}{r}0.0027 \\
(0.012) \\
\end{array}$ & $\begin{array}{l}-0.0759 * * * \\
(0.014)\end{array}$ & $\begin{array}{r}-0.0002 \\
(0.001) \\
\end{array}$ & $\begin{array}{l}-0.0117 \text { *** } \\
(0.004)\end{array}$ \\
\hline \multirow{9}{*}{ 蒿 } & Excessive loan growth & $\begin{array}{l}0.0385 \text { *** } \\
(0.005)\end{array}$ & $\begin{array}{l}0.1597^{* * *} \\
(0.027)\end{array}$ & $\begin{array}{l}0.2765 * * * \\
(0.075)\end{array}$ & $\begin{array}{l}0.0544 \\
(0.091)\end{array}$ & $\begin{array}{l}0.4453 \text { *** } \\
(0.008)\end{array}$ & $\begin{array}{l}0.0004^{* * *} \\
(0.000)\end{array}$ & $\begin{array}{l}-0.0230 \\
(0.037)\end{array}$ \\
\hline & Non-interest income & $\begin{array}{l}-0.0034 * * * \\
(0.000)\end{array}$ & $\begin{array}{l}-0.0043 * * \\
(0.002)\end{array}$ & $\begin{array}{r}-0.0099 \\
(0.011) \\
\end{array}$ & $\begin{array}{r}-0.0068 \\
(0.014) \\
\end{array}$ & $\begin{array}{l}-0.2350 * * * \\
(0.001)\end{array}$ & $\begin{array}{r}-0.0001 \\
(0.005) \\
\end{array}$ & $\begin{array}{l}-0.0046 * \\
(0.003)\end{array}$ \\
\hline & Constant & $\begin{array}{l}-2.8028 * * * \\
(0.391) \\
\end{array}$ & $\begin{array}{l}-1.3420 \text { *** } \\
(0.257) \\
\end{array}$ & $\begin{array}{l}-5.9516 \text { *** } \\
(1.258) \\
\end{array}$ & $\begin{array}{l}-0.5569 \\
(0.997) \\
\end{array}$ & $\begin{array}{l}2.9702 * * * \\
(0.143)\end{array}$ & $\begin{array}{l}-0.0074 \text { *** } \\
(0.001) \\
\end{array}$ & $\begin{array}{l}-0.3538 \\
(0.362) \\
\end{array}$ \\
\hline & No. of observations & 852 & 483 & 483 & 547 & 83 & 483 & 483 \\
\hline & $\mathrm{R}^{2}$ & 0.111 & 0.517 & 0.378 & 0.025 & 0.641 & 0.086 & 0.059 \\
\hline & \multicolumn{8}{|c|}{ Percent true positives/negatives $54.84 / 76.53$} \\
\hline & Percent correctly classified & 75.0 & & & & & & \\
\hline & Hosmer-Lemeshow test & 4.44 & & & & & & \\
\hline & Hosmer-Lemeshow test p-valu & 0.8155 & & & & & & \\
\hline
\end{tabular}


Table IV

Effects of Balance Sheet Structures on Bank Risk before the Crisis

This table reports the results from our primary bank risk regressions before the 2007-2009 crisis. Columns (I) to (V) contain the coefficients of OLS regressions where bank risk is measured as systematic risk, systemic risk, structural credit risk and two measures idiosyncratic risk. See Section II for further details and Table I for variables' definitions. The dependent variables are calculated as averages of quarterly data for individual banks during the 2006Q1 to 2006Q4 period. The variables accounting for size, capital structure, asset structure, funding structure and income structure are calculated from the averages of quarterly data for individual banks during the 2003Q4 to 2005Q4 period. *, ** and *** indicate statistical significance at the $10 \%$, 5\% and $1 \%$ levels, respectively.

\begin{tabular}{|c|c|c|c|c|c|c|}
\hline \multicolumn{7}{|c|}{ Dependent Variable: Measures of Bank Risk } \\
\hline & \multirow{2}{*}{ Dependent Variable: } & $\begin{array}{r}\text { Systematic } \\
\text { risk }\end{array}$ & $\begin{array}{c}\text { Systemic } \\
\text { risk }\end{array}$ & $\begin{array}{l}\text { Structural } \\
\text { credit risk }\end{array}$ & $\begin{array}{r}\text { Idiosyncratic } \\
\text { risk1 }\end{array}$ & $\begin{array}{r}\text { Idiosyncratic } \\
\text { risk2 }\end{array}$ \\
\hline & & (I) & (II) & (III) & (IV) & (V) \\
\hline & \multirow[t]{2}{*}{ Size } & $0.1991 * * *$ & $0.2962 * * *$ & $0.0409 * * *$ & $-0.0119 * * *$ & $0.0108 * * *$ \\
\hline & & $(0.0178)$ & $(0.011)$ & $(0.0093)$ & $(0.0021)$ & $(0.0020)$ \\
\hline \multirow{4}{*}{ 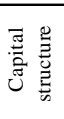 } & \multirow[t]{2}{*}{ Capital } & -0.0011 & -0.0141 & $-0.0139 * * *$ & 0.0000 & 0.0011 \\
\hline & & $(0.0092)$ & $(0.010)$ & $(0.0041)$ & $(0.0011)$ & $(0.0009)$ \\
\hline & \multirow[t]{2}{*}{ Undercapitalized } & $-0.0702 * * *$ & $-0.0443 * *$ & $-0.0231 * *$ & $0.0061 * *$ & $-0.0041 *$ \\
\hline & & $(0.0154)$ & $(0.020)$ & $(0.0107)$ & $(0.0024)$ & $(0.0022)$ \\
\hline \multirow{4}{*}{$\begin{array}{l}\text { 总 } \\
\text { 娄 } \\
\text { 至 }\end{array}$} & \multirow[t]{2}{*}{ Loans to total assets } & $0.0124 * * *$ & 0.0060 & 0.0002 & -0.0005 & 0.0002 \\
\hline & & $(0.0031)$ & $(0.004)$ & $(0.0016)$ & $(0.0004)$ & $(0.0002)$ \\
\hline & \multirow[t]{2}{*}{ Securitization } & $-0.0968 *$ & 0.0296 & -0.0015 & 0.0017 & -0.0001 \\
\hline & & $(0.0529)$ & $(0.080)$ & $(0.0232)$ & $(0.0088)$ & $(0.0033)$ \\
\hline \multirow{4}{*}{ 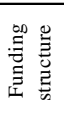 } & \multirow[t]{2}{*}{ Short-term market funding } & $0.0177 * * *$ & $0.0112 * * *$ & $-0.0031 *$ & -0.0001 & -0.0002 \\
\hline & & $(0.0036)$ & $(0.003)$ & $(0.0018)$ & $(0.0004)$ & $(0.0003)$ \\
\hline & \multirow[t]{2}{*}{ Deposit funding } & $-0.0214 * * *$ & $-0.0142 * *$ & $-0.0028 *$ & 0.0008 & $-0.0005 *$ \\
\hline & & $(0.0032)$ & $(0.006)$ & $(0.0016)$ & $(0.0005)$ & $(0.0003)$ \\
\hline \multirow{8}{*}{$\begin{array}{l}\text { 号 } \\
\text { 总 } \\
\text { 至 }\end{array}$} & \multirow[t]{2}{*}{ Excessive loan growth } & $0.0174 *$ & $0.0290 * * *$ & $0.0120 * * *$ & -0.0009 & $0.0011 *$ \\
\hline & & $(0.0094)$ & $(0.006)$ & $(0.0046)$ & $(0.0013)$ & $(0.0007)$ \\
\hline & \multirow[t]{2}{*}{ Non-interest income } & -0.0023 & -0.0008 & -0.0020 & 0.0004 & $-0.0006 *$ \\
\hline & & $(0.0020)$ & $(0.002)$ & $(0.0013)$ & $(0.0003)$ & $(0.0003)$ \\
\hline & \multirow[t]{2}{*}{ Intercept } & $-1.6796 * * *$ & $-1.3968 * * *$ & -0.2310 & $0.1691 * * *$ & $-0.1140 * * *$ \\
\hline & & $(0.3470)$ & $(0.499)$ & $(0.1685)$ & $(0.0441)$ & $(0.0214)$ \\
\hline & No. of observations & 426 & 426 & 544 & 426 & 426 \\
\hline & $\mathrm{R}^{2}$ & 0.231 & 0.343 & 0.120 & 0.109 & 0.187 \\
\hline
\end{tabular}


Table V

Quantile Estimates for Systematic Risk:

The Distributional Effects of Bank Balance Sheet Structures on Bank Risk

This table reports the regression quantile estimates of our baseline specification, using individual bank systematic risk as dependent variable. See Table I for variables' definitions. Columns (I) to (V) contain the coefficients of quantile estimates regressions for the $10 \%, 25 \%, 50 \%, 75 \%$ and $90 \%$ quantiles of bank systematic risk calculated as averages of quarterly data during the pre-crisis period (2007Q4 to 2009Q4). The variables accounting for size, capital structure, asset structure, funding structure and income structure are calculated from the averages of quarterly data for individual banks during the pre-crisis period (2003Q4 to 2007Q3). The equality test applied is the F-test where the null hypothesis purports that the estimated slope coefficients for each variable are not statistically different across all the quantile estimates. The p-value for this test is given below the equality test value. $*, * *$ and $* * *$ indicate statistical significance at the $10 \%, 5 \%$ and $1 \%$ levels, respectively.

\begin{tabular}{|c|c|c|c|c|c|c|c|c|c|c|c|c|}
\hline & & $\begin{array}{l}\text { Q10 } \\
\text { (I) }\end{array}$ & & $\begin{array}{l}\text { Q25 } \\
\text { (II) }\end{array}$ & & $\begin{array}{l}\text { Q50 } \\
\text { (III) }\end{array}$ & & $\begin{array}{l}\text { Q75 } \\
\text { (IV) }\end{array}$ & & $\begin{array}{l}\text { Q90 } \\
\text { (V) }\end{array}$ & & $\begin{array}{l}\text { Equality } \\
\text { Test }^{1}\end{array}$ \\
\hline & \multirow[t]{2}{*}{ Size } & 0.1207 & *** & 0.1148 & **** & 0.0949 & ** & 0.1209 & ** & 0.0724 & & 0.490 \\
\hline & & $(0.032)$ & & $(0.034)$ & & $(0.038)$ & & $(0.050)$ & & $(0.047)$ & & 0.743 \\
\hline \multirow{4}{*}{ 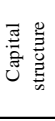 } & Capital & 0.0128 & & -0.0005 & & -0.0067 & & -0.0290 & $* *$ & -0.0476 & $* * *$ & 3.170 \\
\hline & & $(0.008)$ & & $(0.009)$ & & $(0.010)$ & & $(0.013)$ & & $(0.012)$ & & 0.076 \\
\hline & Undercapitalized & -0.0559 & $* * *$ & -0.0649 & $* * *$ & -0.0615 & $* * *$ & -0.0751 & $* * *$ & -0.0889 & $* * *$ & 0.490 \\
\hline & & $(0.014)$ & & $(0.016)$ & & $(0.017)$ & & $(0.022)$ & & $(0.021)$ & & 0.740 \\
\hline \multirow{4}{*}{ 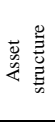 } & Loans to total assets & -0.0007 & & -0.0005 & & 0.0033 & & 0.0107 & $* * *$ & 0.0065 & * & 9.800 \\
\hline & & $(0.003)$ & & $(0.003)$ & & $(0.003)$ & & $(0.004)$ & & $(0.004)$ & & 0.002 \\
\hline & Securitisation & 0.0277 & & -0.0140 & & -0.1058 & * & -0.1332 & * & -0.1768 & ** & 8.160 \\
\hline & & $(0.054)$ & & $(0.054)$ & & $(0.058)$ & & $(0.076)$ & & $(0.074)$ & & 0.005 \\
\hline \multirow{4}{*}{ 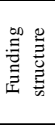 } & Short-term market funding & 0.0014 & & 0.0029 & & 0.0074 & ** & 0.0161 & $* * *$ & 0.0146 & $* * *$ & 12.430 \\
\hline & & $(0.003)$ & & $(0.003)$ & & $(0.004)$ & & $(0.005)$ & & $(0.005)$ & & 0.001 \\
\hline & Deposit funding & -0.0145 & $* * *$ & -0.0151 & $* * *$ & -0.0194 & $* * *$ & -0.0298 & $* * *$ & -0.0321 & $* * *$ & 8.110 \\
\hline & & $(0.003)$ & & $(0.003)$ & & $(0.003)$ & & $(0.004)$ & & $(0.004)$ & & 0.005 \\
\hline \multirow{8}{*}{ 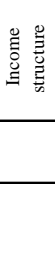 } & Excessive loan growth & 0.0589 & ** & 0.0840 & $* * *$ & 0.1396 & $* * *$ & 0.1294 & $* * *$ & 0.1443 & *** & 4.270 \\
\hline & & $(0.027)$ & & $(0.030)$ & & $(0.034)$ & & $(0.044)$ & & $(0.041)$ & & 0.039 \\
\hline & Non-interest income & 0.0025 & & 0.0026 & & -0.0024 & & -0.0053 & & -0.0071 & $* *$ & 3.400 \\
\hline & & $(0.002)$ & & $(0.002)$ & & $(0.003)$ & & $(0.003)$ & & $(0.003)$ & & 0.066 \\
\hline & Intercept & -1.1053 & $* * *$ & -0.9905 & $* * *$ & -1.0841 & $* * *$ & -1.0673 & ** & 0.0059 & & \\
\hline & & $(0.275)$ & & $(0.299)$ & & $(0.333)$ & & $(0.433)$ & & $(0.409)$ & & \\
\hline & No. of observations & 483 & & 483 & & 483 & & 483 & & 483 & & \\
\hline & Pseudo $R^{2}$ & 0.175 & & 0.270 & & 0.353 & & 0.287 & & 0.218 & & \\
\hline
\end{tabular}


Table VI

Effect of Size on Bank Risk

This table reports the results from our bank risk regressions accounting for non-linear effects for bank size. Column (I) reports the results of the probit regression using government support as a measure of bank risk. Columns (II) to (VII) contain the coefficients of OLS regressions where bank risk is measured as systematic risk, systemic risk, structural credit risk, centra bank liquidity and two measures of idiosyncratic risk. See Section II for further details and Table I for variables' definitions. The dependent variables are calculated as averages of quarterly data for individual banks during the pre-crisis period (2007Q4 to 2009Q4) except for the variable accounting for central bank liquidity. The latter is constructed only for the period of ful liquidity allotment by the European Central Bank (2009Q1 to 2009Q4). The variables accounting for size, capital structure, asset structure, funding structure and income structure are calculated from the averages of quarterly data for individual banks during the pre-crisis period (2003Q4 to 2007Q3). *, ** and *** indicate statistical significance at the $10 \%, 5 \%$ and $1 \%$ levels respectively.

\begin{tabular}{|c|c|c|c|c|c|c|c|c|}
\hline & & \multicolumn{6}{|c|}{ Dependent Variable: Measures of Bank Risk } & \multirow[b]{2}{*}{$\begin{array}{r}\text { Idiosyncratic } \\
\text { risk II }\end{array}$} \\
\hline & & Rescue & $\begin{array}{r}\text { Systematic } \\
\text { risk }\end{array}$ & $\begin{array}{r}\text { Systemic } \\
\text { risk }\end{array}$ & $\begin{array}{l}\text { Structural } \\
\text { credit risk }\end{array}$ & $\begin{array}{r}\text { Central } \\
\text { bank } \\
\text { liquidity }\end{array}$ & $\begin{array}{r}\text { Idiosyncratic } \\
\text { risk I }\end{array}$ & \\
\hline & & (I) & (II) & (III) & (IV) & (V) & (VI) & (VII) \\
\hline \multicolumn{2}{|r|}{ Size } & $\begin{array}{l}0.0278^{* * *} \\
(0.004)\end{array}$ & $\begin{array}{l}0.2138 \text { *** } \\
(0.022)\end{array}$ & $\begin{array}{l}0.9033^{* * *} \\
(0.188)\end{array}$ & $\begin{array}{l}0.0590 \\
(0.076) \\
\end{array}$ & $\begin{array}{r}-0.1489 \\
(1.050) \\
\end{array}$ & $\begin{array}{l}0.0012 * \\
(0.001) \\
\end{array}$ & $\begin{array}{l}0.1117^{* *} \\
(0.044) \\
\end{array}$ \\
\hline \multicolumn{2}{|r|}{ Size square } & $\begin{array}{l}0.0037 \text { *** } \\
(0.001)\end{array}$ & $\begin{array}{l}-0.0339 \text { *** } \\
(0.006)\end{array}$ & $\begin{array}{l}-0.0857 * * * \\
(0.022)\end{array}$ & $\begin{array}{l}-0.0407^{* * *} \\
0.014036\end{array}$ & $\begin{array}{l}-0.0766 \\
(0.127) \\
\end{array}$ & $\begin{array}{l}-0.0002 * * * \\
(0.000)\end{array}$ & $\begin{array}{c}-0.0058 \\
(0.005) \\
\end{array}$ \\
\hline \multirow{2}{*}{ 丞兽 } & Capital & $\begin{array}{l}-0.0203 * * * \\
(0.001)\end{array}$ & $\begin{array}{l}-0.0081 * \\
(0.004)\end{array}$ & $\begin{array}{l}-0.0446 * * \\
(0.018)\end{array}$ & $\begin{array}{l}-0.05811^{* * *} \\
(0.009)\end{array}$ & $\begin{array}{l}-0.1858 * * * \\
(0.051)\end{array}$ & $\begin{array}{l}-0.0001 \\
(0.000)\end{array}$ & $\begin{array}{r}-0.0014 \\
(0.011)\end{array}$ \\
\hline & Undercapitalized & $\begin{array}{l}-0.0439 * * * \\
(0.007)\end{array}$ & $\begin{array}{l}-0.0647 \text { *** } \\
(0.009)\end{array}$ & $\begin{array}{l}-0.0832 * * * \\
(0.029)\end{array}$ & $\begin{array}{l}-0.0979 * * * \\
(0.022)\end{array}$ & $\begin{array}{l}-0.1170 * * * \\
(0.025)\end{array}$ & $\begin{array}{l}-0.0007 * * \\
(0.000)\end{array}$ & $\begin{array}{r}-0.0042 \\
(0.019) \\
\end{array}$ \\
\hline \multirow{2}{*}{ 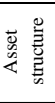 } & Loans to total assets & $\begin{array}{l}0.0053 \text { *** } \\
(0.001)\end{array}$ & $\begin{array}{l}0.0009 \\
(0.003)\end{array}$ & $\begin{array}{l}0.0192 * \\
(0.011)\end{array}$ & $\begin{array}{l}0.0155 * \\
(0.009)\end{array}$ & $\begin{array}{l}0.0130 \\
(0.017)\end{array}$ & $\begin{array}{l}0.0000 \\
(0.000)\end{array}$ & $\begin{array}{r}-0.0040 \\
(0.003)\end{array}$ \\
\hline & Securitization & $\begin{array}{l}-0.0120 * * * \\
(0.001)\end{array}$ & $\begin{array}{l}-0.1560 * * * \\
(0.018)\end{array}$ & $\begin{array}{l}-0.5681 * * * \\
(0.064)\end{array}$ & $\begin{array}{l}-0.2421 * * \\
(0.112)\end{array}$ & $\begin{array}{r}-0.3407 \\
(0.295) \\
\end{array}$ & $\begin{array}{l}0.0004 \\
(0.001) \\
\end{array}$ & $\begin{array}{l}0.0562 \\
(0.071) \\
\end{array}$ \\
\hline \multirow{2}{*}{ 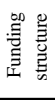 } & Short-term market funding & $\begin{array}{l}0.0076 * * * \\
(0.001)\end{array}$ & $\begin{array}{l}0.0058 \text { *** } \\
(0.001)\end{array}$ & $\begin{array}{l}0.0405 * * * \\
(0.014)\end{array}$ & $\begin{array}{l}0.0262 * * * \\
(0.006)\end{array}$ & $\begin{array}{l}0.0737 \text { *** } \\
(0.004)\end{array}$ & $\begin{array}{l}0.0001 \\
(0.000)\end{array}$ & $\begin{array}{r}-0.0029 \\
(0.004)\end{array}$ \\
\hline & Deposit funding & $\begin{array}{l}-0.0106 * * * \\
(0.001)\end{array}$ & $\begin{array}{l}-0.0210 * * * \\
(0.005)\end{array}$ & $\begin{array}{l}-0.0657 * * * \\
(0.021)\end{array}$ & $\begin{array}{l}0.0081 \\
(0.019) \\
\end{array}$ & $\begin{array}{l}-0.0586 * * * \\
(0.013)\end{array}$ & $\begin{array}{l}-0.0002 * * * \\
(0.000)\end{array}$ & $\begin{array}{l}-0.0117 \text { *** } \\
(0.004) \\
\end{array}$ \\
\hline \multirow{9}{*}{ 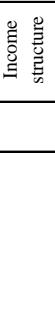 } & Excessive loan growth & $\begin{array}{l}0.0409 * * * \\
(0.004)\end{array}$ & $\begin{array}{l}0.1628 * * * \\
(0.025)\end{array}$ & $\begin{array}{l}0.3380 \text { *** } \\
(0.094)\end{array}$ & $\begin{array}{l}0.0739 * \\
(0.043)\end{array}$ & $\begin{array}{l}0.6951 \text { *** } \\
(0.062)\end{array}$ & $\begin{array}{l}0.0006 \\
(0.001)\end{array}$ & $\begin{array}{r}-0.0205 \\
(0.037)\end{array}$ \\
\hline & Non-interest income & $\begin{array}{l}-0.0034 * * * \\
(0.000)\end{array}$ & $\begin{array}{l}-0.0019 * \\
(0.001)\end{array}$ & $\begin{array}{r}-0.0047 \\
(0.008) \\
\end{array}$ & $\begin{array}{r}-0.0001 \\
(0.004) \\
\end{array}$ & $\begin{array}{l}-0.2165 * * * \\
(0.010)\end{array}$ & $\begin{array}{r}-0.0001 \\
(0.000) \\
\end{array}$ & $\begin{array}{r}-0.0044 \\
(0.003)\end{array}$ \\
\hline & Constant & $\begin{array}{l}-2.7531 \text { *** } \\
(0.434)\end{array}$ & $\begin{array}{l}-1.6622 * * * \\
(0.312)\end{array}$ & $\begin{array}{l}-6.3235 * * * \\
(1.506)\end{array}$ & $\begin{array}{r}-0.7868 \\
(1.206) \\
\end{array}$ & $\begin{array}{l}5.2570 \\
(8.489)\end{array}$ & $\begin{array}{l}-0.0088 * \\
(0.005)\end{array}$ & $\begin{array}{r}-0.3757 \\
(0.362) \\
\end{array}$ \\
\hline & No. of observations & 852 & 483 & 483 & 547 & 83 & 483 & 483 \\
\hline & $\mathrm{R}^{2}$ & 0.113 & 0.583 & 0.407 & 0.032 & 0.513 & 0.106 & 0.062 \\
\hline & Percent true positives/negatives & $76.81 / 59.02$ & & & & & & \\
\hline & Percent correctly classified & 75.6 & & & & & & \\
\hline & Hosmer-Lemeshow test & 10.77 & & & & & & \\
\hline & Hosmer-Lemeshow test p-value & 0.215 & & & & & & \\
\hline
\end{tabular}


Table VII

Robustness Tests on the Effects of Balance sheet Structures on Bank Risk

This table reports the results from our robustness tests on our bank risk regressions. It includes additional controls to the baseline specification presented in Table III. The majority of the results remain robust to the inclusion of country dummies, as well of additional variables capturing banks' profitability, and major country macroeconomic developments, such as GDP growth, house prices and stock market returns. Columns (I) and (II) report the results of the probit regression using government support as a measure of bank risk. Columns (III) to (IX) contain the coefficients of OLS regressions where bank risk is measured as systematic risk, systemic risk, structural credit risk, and central bank liquidity. See Section II for further details and Table I for variables' definitions. The dependent variables are calculated as averages of quarterly data for individual banks during the pre-crisis period (2007Q4 to 2009Q4) except for the variable accounting for central bank liquidity. The latter is constructed only for the period of full liquidity allotment by the European Central Bank (2009Q1 to 2009Q4). The variables accounting for size, capital structure, asset structure, funding structure, income structure and profitability are calculated from the averages of quarterly data for individual banks during the pre-crisis period (2003Q4 to 2007Q3). GDP growth, house prices and stock market are calculated as country averages from quarterly data during the pre-crisis period already mentioned. *,** and *** indicate statistical significance at the $10 \%, 5 \%$ and $1 \%$ levels, respectively.

\begin{tabular}{|c|c|c|c|c|c|c|c|c|c|c|}
\hline & & \multicolumn{9}{|c|}{ Dependent Variable: Measures of Bank Risk } \\
\hline & & \multicolumn{2}{|c|}{ Rescue } & \multicolumn{2}{|c|}{ Systematic risk } & \multicolumn{2}{|c|}{ Systemic risk } & \multicolumn{2}{|c|}{ Structural credit risk } & \multirow{2}{*}{$\begin{array}{c}\text { Central bank } \\
\text { liquidity } \\
\text { (IX) }\end{array}$} \\
\hline & & (I) & (II) & (III) & (IV) & $(\mathrm{V})$ & (VI) & (VII) & (VIII) & \\
\hline & Size & $0.0563 *$ & $0.0369 * * *$ & $0.1329 * * *$ & $0.1161 * * *$ & $0.7082 * * *$ & $0.6307 * * *$ & -0.0460 & -0.0829 & $-0.5844 * * *$ \\
\hline & & $(0.029)$ & $(0.014)$ & $(0.019)$ & $(0.038)$ & $(0.101)$ & $(0.162)$ & $(0.048)$ & $(0.145)$ & $(0.042)$ \\
\hline \multirow{4}{*}{ 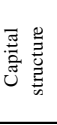 } & Capital & $-0.0248 * * *$ & $-0.0240 * * *$ & -0.0005 & $-0.0185 * *$ & -0.0191 & $-0.0583 * * *$ & $-0.0478 * * *$ & $-0.0588 * *$ & $-0.3308 * * *$ \\
\hline & & $(0.001)$ & $(0.001)$ & $(0.002)$ & $(0.008)$ & $(0.013)$ & $(0.011)$ & $(0.007)$ & $(0.023)$ & $(0.043)$ \\
\hline & Undercapitalized & -0.0059 & $-0.0206 * * *$ & $-0.0360 * * *$ & $-0.0462 * *$ & $-0.1117 * *$ & $-0.0915 * *$ & $-0.1004 * * *$ & -0.0392 & $-0.1115 * * *$ \\
\hline & & 0.0145 & $(0.002)$ & $(0.011)$ & $(0.018)$ & $(0.049)$ & $(0.038)$ & $(0.025)$ & $(0.066)$ & $(0.005)$ \\
\hline \multirow{4}{*}{ 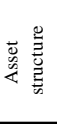 } & Loans to total assets & $0.0033 * * *$ & $0.0032 * * *$ & 0.0036 & $0.0048 *$ & $0.0337 * * *$ & $0.0323 * * *$ & $0.0233 * *$ & $0.0221 * * *$ & $0.0695 * * *$ \\
\hline & & $(0.000)$ & $(0.000)$ & $(0.002)$ & $(0.003)$ & $(0.012)$ & $(0.011)$ & $(0.010)$ & $(0.008)$ & $(0.004)$ \\
\hline & Securitization & $-0.0099 * * *$ & $-0.0046 * * *$ & -0.1097 & $-0.1337 * *$ & $-0.6977 * * *$ & $-0.5169 * * *$ & -0.1702 & -0.1055 & $-0.9080 * * *$ \\
\hline & & $(0.001)$ & $(0.001)$ & $(0.125)$ & $(0.061)$ & $(0.141)$ & $(0.147)$ & $(0.122)$ & $(0.143)$ & $(0.096)$ \\
\hline \multirow{4}{*}{ 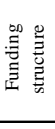 } & Short-term market funding & $0.0028 * * *$ & $0.0034 * * *$ & $0.0037 *$ & $0.0080 * * *$ & $0.0420 * * *$ & $0.0485 * * *$ & $0.0284 * * *$ & $0.0289 * *$ & $0.1403 * * *$ \\
\hline & & $(0.000)$ & $(0.000)$ & $(0.002)$ & $(0.003)$ & $(0.013)$ & $(0.012)$ & $(0.007)$ & $(0.015)$ & $(0.009)$ \\
\hline & Deposit funding & $-0.0069 * * *$ & $-0.0068 * * *$ & $-0.0081 * * *$ & $-0.0147 * * *$ & $-0.0442 * * *$ & $-0.0462 * * *$ & 0.0190 & 0.0269 & $-0.0628 * * *$ \\
\hline & & $(0.001)$ & $(0.001)$ & $(0.002)$ & $(0.003)$ & $(0.013)$ & $(0.014)$ & $(0.023)$ & $(0.021)$ & $(0.017)$ \\
\hline \multirow{4}{*}{ 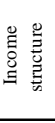 } & Excessive loan growth & $0.0422 *$ & $0.0548 * * *$ & $0.1429 * * *$ & $0.1504 * * *$ & $0.3045 * * *$ & $0.3313 * * *$ & 0.0539 & 0.0748 & $0.7737 * * *$ \\
\hline & & $(0.023)$ & $(0.008)$ & $(0.042)$ & $(0.030)$ & $(0.051)$ & $(0.087)$ & $(0.043)$ & $(0.118)$ & $(0.022)$ \\
\hline & Non-interest income & $-0.0028 * * *$ & $-0.0023 * * *$ & -0.0013 & -0.0037 & -0.0091 & -0.0028 & 0.0004 & 0.0024 & $-0.2574 * * *$ \\
\hline & & $(0.000)$ & $(0.000)$ & $(0.002)$ & $(0.002)$ & $(0.007)$ & $(0.006)$ & $(0.004)$ & $(0.019)$ & $(0.010)$ \\
\hline \multirow{8}{*}{ 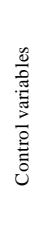 } & Profitability & & $-0.0208 * * *$ & & $0.1391 * *$ & & 0.1805 & & -0.0647 & 0.7259 \\
\hline & & & $(0.008)$ & & $(0.055)$ & & $(0.193)$ & & $(0.419)$ & $(0.732)$ \\
\hline & GDP growth & & 0.1875 & & $0.2913 * * *$ & & $2.0110 * * *$ & & 0.5782 & $1.6483 * * *$ \\
\hline & & & $(0.215)$ & & $(0.107)$ & & $(0.269)$ & & $(0.499)$ & $(0.487)$ \\
\hline & House prices & & $0.1857 * *$ & & $0.1384 * * *$ & & 0.4074 & & 0.3905 & \\
\hline & & & $(0.073)$ & & $(0.041)$ & & $(0.115)$ & & $(0.155)$ & \\
\hline & Stock market & & $-0.0659 * * *$ & & $-0.1199 * * *$ & & 0.1107 & & -0.2495 & \\
\hline & & & $(0.002)$ & & $(0.038)$ & & $(0.186)$ & & $(0.108)$ & \\
\hline & Country dummies & Yes & & Yes & & Yes & & Yes & & \\
\hline & Intercept & $-2.4757 * * *$ & $-3.5289 * * *$ & $-1.3049 * * *$ & $-1.7491 * * *$ & $-6.2326 * * *$ & $-9.1621 * * *$ & -0.7607 & -1.4011 & $2.5345 * * *$ \\
\hline & & $(0.227)$ & $(0.650)$ & $(0.286)$ & $(0.330)$ & $(1.349)$ & (1.604) & $(1.131)$ & (1.109) & $(0.906)$ \\
\hline & No. of observations & 852 & 852 & 483 & 483 & 483 & 483 & 547 & 547 & 83 \\
\hline & $\mathrm{R}^{2}$ & 0.137 & 0.124 & 0.568 & 0.551 & 0.410 & 0.416 & 0.032 & 0.037 & 0.676 \\
\hline & Percent true positives/negatives & $59.30 / 75.55$ & $52.94 / 77.25$ & & & & & & & \\
\hline & Percent correctly classified & 73.7 & 74.86 & & & & & & & \\
\hline & Hosmer-Lemeshow test & 3.24 & 9.99 & & & & & & & \\
\hline & Hosmer-Lemeshow test p-value & 0.9187 & 0.2654 & & & & & & & \\
\hline
\end{tabular}


Table VIII

Robustness Tests on Balance Sheet Structures on Bank Risk

Splitting the samples according to M\&A activities and types of ownership

This table presents the results of the baseline specification presented in Table III, after splitting the sample between banks which have been or not involved in an M\&A activity, or alternatively, between banks with a more or less dispersed ownership structure. The idea is that management and shareholder's risk preferences are unlikely to remain the same across these different groups. The results show that our findings remain robust to different groupings of banks. Columns (I) and (IV) report the results of the probit regression using government support as a measure of bank risk. See Section II for further details and Table I for variables' definitions. The variables accounting for size, capital structure, asset structure, funding structure and income structure are calculated from the averages of quarterly data for individual banks during the pre-crisis period (2003Q4 to 2007Q3). *, ** and $* * *$ indicate statistical significance at the $10 \%, 5 \%$ and $1 \%$ levels, respectively. *, **, and *** indicate statistical significance at the $10 \%, 5 \%$ and $1 \%$ levels, respectively.

\begin{tabular}{|c|c|c|c|c|c|}
\hline & & \multicolumn{2}{|c|}{ M\&A Activities } & \multicolumn{2}{|c|}{ Ownership } \\
\hline & & $\begin{array}{c}\text { Not-involved } \\
\text { (I) }\end{array}$ & $\begin{array}{c}\text { Involved } \\
\text { (II) }\end{array}$ & $\begin{array}{l}\text { Dispersed } \\
\text { (III) }\end{array}$ & $\begin{array}{c}\text { Concentrated } \\
\text { (III) }\end{array}$ \\
\hline & Size & $0.0572 * * *$ & $-0.1145 * * *$ & 0.0375 & -0.0001 \\
\hline & & $(0.0055)$ & $(0.0378)$ & $(0.0563)$ & $(0.0013)$ \\
\hline \multirow{4}{*}{ 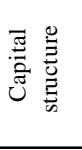 } & Capital & $-0.0217 * * *$ & $-0.0227 * * *$ & $-0.0291 * * *$ & $-0.0023 *$ \\
\hline & & $(0.0015)$ & $(0.0040)$ & $(0.0026)$ & $(0.0012)$ \\
\hline & Undercapitalized & $-0.0323 * * *$ & $-0.0638 *$ & $-0.0548 * * *$ & $0.0012 * * *$ \\
\hline & & $(0.0046)$ & $(0.0344)$ & $(0.0136)$ & $(0.0001)$ \\
\hline \multirow{4}{*}{ 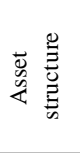 } & Loans to total assets & $0.0077 * * *$ & $-0.0059 * * *$ & $0.0052 * * *$ & $0.0004 * * *$ \\
\hline & & $(0.0003)$ & $(0.0008)$ & $(0.0003)$ & $(0.0001)$ \\
\hline & Securitization & $-0.0140 * * *$ & $-0.1195 * * *$ & $-0.1157 *$ & $-0.0841 * * *$ \\
\hline & & $(0.0006)$ & $(0.0423)$ & $(0.0641)$ & $(0.0261)$ \\
\hline \multirow{4}{*}{ 品导 } & Short-term market funding & $0.0092 * * *$ & -0.0017 & $0.0060 * * *$ & $0.0001 * * *$ \\
\hline & & $(0.0006)$ & $(0.0015)$ & $(0.0009)$ & $(0.0000)$ \\
\hline & Deposit funding & $-0.0097 * * *$ & $-0.0099 * * *$ & $-0.0116 * * *$ & $-0.0009 * *$ \\
\hline & & $(0.0001)$ & $(0.0023)$ & $(0.0016)$ & $(0.0004)$ \\
\hline \multirow{4}{*}{$\begin{array}{l}\stackrel{\Xi}{\Xi} \\
\stackrel{\Xi}{\Xi} \\
\stackrel{\Xi}{\Xi}\end{array}$} & Excessive loan growth & $0.0182 * * *$ & $0.1599 * * *$ & $0.0716 * *$ & $0.0025 *$ \\
\hline & & $(0.004)$ & $(0.044)$ & $(0.032)$ & $(0.001)$ \\
\hline & Non-interest income & $-0.0028 * * *$ & $-0.0022 * * *$ & $-0.0026 * *$ & $-0.0001 * * *$ \\
\hline & & $(0.0004)$ & $(0.0002)$ & $(0.0012)$ & $(0.0000)$ \\
\hline & Intercept & $-4.0723 * * *$ & $1.1960 * * *$ & $-2.6261 * * *$ & $-2.2002 * *$ \\
\hline & & $(0.1460)$ & $(0.4343)$ & $(0.2732)$ & $(1.0076)$ \\
\hline & No. of observations & 651 & 201 & 595 & 89 \\
\hline & $\mathrm{R}^{2}$ & 0.114 & 0.101 & 0.112 & 0.261 \\
\hline & Percent true positives/negatives & $55.77 / 76.20$ & 47.24/77.99 & $50.00 / 78.90$ & 28.21/74.39 \\
\hline & Percent correctly classified & 74.97 & 73.46 & 74.28 & 72.42 \\
\hline & Hosmer-Lemeshow test & 7.14 & 6.57 & 11.56 & 7.64 \\
\hline & Hosmer-Lemeshow test p-value & 0.5215 & 0.5833 & 0.1721 & 0.4690 \\
\hline
\end{tabular}

